\title{
DISC DEGENERATION
}

\section{ITS FREQUENCY AND RELATIONSHIP TO SYMPTOMS}

\author{
BY \\ J. S. LAWRENCE \\ From The Arthritis and Rheumatism Council Field Unit, Manchester
}

Degenerative changes in the intervertebral discs have been recognized by pathologists for a considerable time. They were described by Wenzel (1842) and were also studied by Rokitanski (1855) and by many other pathologists. Extensive studies by Schmorl (1929), begun in Dresden in 1925 on routine autopsy material, revealed the great frequency of degenerative changes in the intervertebral discs and their relationship to disc prolapse (Schmorl and Junghanns, 1951). According to Schmorl, disc tissue is normally the first to show signs of the ageing process. Even in the middle decades of life completely normal discs are the exception rather than the rule. At routine autopsies degenerative discs are found in 10 per cent. of persons aged 20 to 29 , and there is an increase with age to 96 per cent. in those over the age of 60 . Emphasis in the past has been mainly on disc prolapse and little attention has been paid to degenerative disc changes unassociated with prolapse, though it has been recognized that in many instances of sciatic and brachial pain no protusion is found at operation.

Radiological evidence of disc degeneration has been observed since $x$ rays first began to be used. As osteophyte formation is a prominent feature, the label osteoarthritis was at first applied. Collins (1949) suggested that the term osteoarthritis be restricted to degenerative changes in the diarthrodial joints of the spine and that disc degeneration be used for such changes in the intervertebral discs. This seems preferable to the use of generic terms, such as spondylosis, spondylarthrosis, and osteophytosis intervertebralis, for there is evidence that the aetiology of degenerative disease in apophyseal joints and discs may not be identical (Kellgren and Lawrence, 1958). Some authors, however, have restricted the term spondylosis to degenerative processes in the vertebral bodies and intervertebral discs (Payne and Spillane, 1957; Wilkinson, 1960). This is acceptable but would seem to have no advantage over Collins' terminology.

The relationship of $x$-ray changes of disc degeneration to symptoms was first investigated in a survey of rheumatic complaints in coalminers, submitted to routine $x$ ray examination of the cervical and lumbar spine, and the importance of disc degeneration as a cause of both symptoms and incapacity in this occupational group was demonstrated (Kellgren and Lawrence, 1952). Later a population sample in Leigh in Northern England, in which the cervical, dorsal, and lumbar spine were examined, was reported (Lawrence, de Graaff, and Laine, 1963). In this population the 8th dorsal disc was most commonly affected in males and the D7 in females, but there were two further peaks, one at $\mathrm{C} 6$ and the other at L3. The cervical and lumbar spine were more frequently affected in males and the dorsal in females, and the prevalence at all sites increased with age. There was a relationship between cervical disc degeneration and neck-shoulder-brachial pain, and between lumbar disc degeneration and back-hipsciatic pain, particularly in the younger age groups, but the numbers in some age groups were too small for a definite conclusion to be reached. A history or signs suggestive of neurological involvement was comparatively rare, and it was concluded that symptoms arose from strains of adjacent ligaments as a result of mechanical defect from unstable or narrowed discs rather than from nerve root pressure. Caplan, Freedman, and Connelly (1966), from a survey of lumbar spine $x$ rays in miners, concluded that disc degeneration, as measured by disc narrowing, is not an accompaniment of age, though there was a direct relationship between ageing and body spurring.

The present is a more detailed study and is based on population samples examined in Leigh, Wensleydale, Watford, and the Rhondda.

\section{Method}

The methods of sampling and completion rates have been discussed elsewhere (Lawrence and Bennett, 1960; Bremner, 1961; Ansell and Lawrence, 1966; Ball and Lawrence, 1961). In all these surveys a detailed history was taken of symptoms, past and present, and a question was asked on loss of work due to rheumatic complaints. Symptoms at each site were classified as occurring in a single attack, in episodes, or as a chronic malady. The 
term "episodic" was used when there had been more than one attack and the term "chronic" when an attack had lasted more than 3 months. When there had been only one attack and it had lasted 3 months or less it was classified as "single".

Clinical Examination.-A detailed examination was made of the musculo-skeletal system and the knee and ankle jerks were tested. A more detailed neurological examination was included only when indicated by the symptoms.

In Leigh, Wensleydale, and Watford, routine lateral radiographs were taken of the cervical spine in persons aged 15 and over and of the lumbar spine in those aged 35 and over. In the Rhondda, however, only the cervical spine was included. Routine $x$ rays of the hands and feet were also taken. The $x$ rays were read "blind" without knowledge of age, sex, or clinical features. Disc degeneration was graded 0-4 on the worst affected disc in each region, the grading being based on the Atlas of Standard Radiographs of Arthritis (1963) (Figs. 1 and 2).

Accurate localization of pain is difficult in a population sample since symptoms are not usually present at the time of the examination. To determine the relationship of disc lesions to distribution of pain more accurately, a comparison was made between $x$ rays and symptoms in a group of coal miners attending a rehabilitation centre with complaints of musculo-skeletal pain of segmental distribution and in whom an $x$ ray showed changes of disc degeneration.

\section{Completion Rate}

Of the 2,103 males in the samples, 1,803 (86 per cent.) had the cervical spine $x$-rayed, and of the 1,844 females, 1,572 (85 per cent.) were $x$-rayed. The completion rate was more adequate in the young and middle aged, those aged 55 and over being less co-operative, but in no age group was the completion rate less than 82 per cent. The number with lumbar spine $x$ rays was less since this part of the spine was not $x$-rayed in the Rhondda population

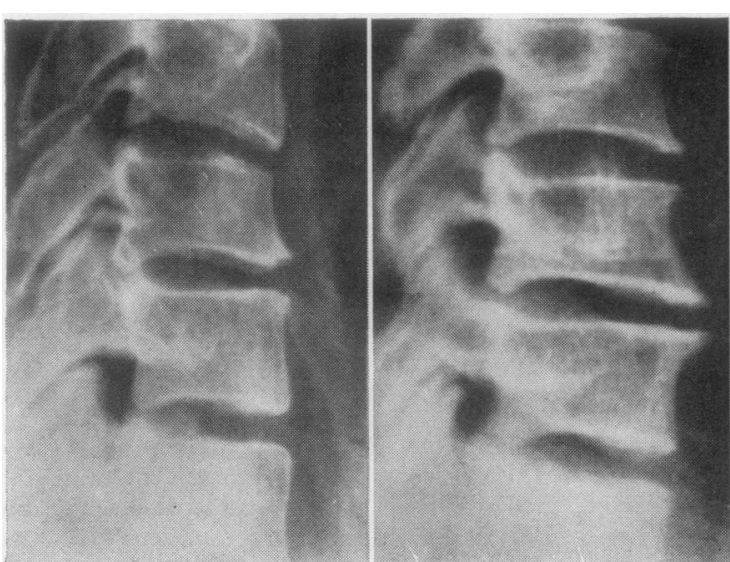

Fig. 1.-Cervical disc degeneration.

Grade 1. Slight anterior wear of vertebral lip sample, nor in subjects below the age of 35 in any of the samples. There were, moreover, a number of respondents who were unable to come to the $x$-ray centre; these were $x$-rayed at home, but the equipment was not $\square$ sufficiently powerful to take clear radiographs of the lumbar spine. Thus only 713 males (72 per cent.) and $\vec{\Rightarrow}$ 809 females (70 per cent.) over 34 years old in the Leigh, $\stackrel{0}{+}$ Wensleydale, and Watford surveys had the lumbar spine $\bar{C}$ $x$-rayed.

\section{Symptoms}

\section{Results}

The majority of the individuals questioned during these surveys gave a history of musculo-skeletal pain at some time in the past, and the most frequent $\overrightarrow{\vec{\omega}}$ site was the lower back often with referral of pain to one or both lower limbs, but other segmental pains were common, especially those in the cervicobrachial distribution.

Neck-shoulder-brachial pain was in fact present in $\vec{N}$ 155 ( 9 per cent.) of the 1,803 males and in 181 (12 per cent.) of the 1,572 females with cervical $x$ rays (Table I). In addition 501 males and 529 females

TABLE I

DISTRIBUTION OF NECK-SHOULDER-BRACHIAL PAIN, BY SEX

\begin{tabular}{|c|c|c|c|c|}
\hline \multirow{2}{*}{ Site of Pain } & \multicolumn{2}{|c|}{ Males } & \multicolumn{2}{|c|}{ Females } \\
\hline & Past & Present & Past & Present \\
\hline $\begin{array}{l}\text { Neck only } \\
\text { Shoulder only } \\
\text { Brachial only } \\
\text { Neck and shoulder } \\
\text { Neck and brachial } \\
\text { Shoulder and brachial } \\
\text { Neck-shoulder-brachial }\end{array}$ & $\begin{array}{r}152 \\
174 \\
22 \\
83 \\
18 \\
34 \\
18\end{array}$ & $\begin{array}{r}13 \\
48 \\
6 \\
35 \\
13 \\
20 \\
20\end{array}$ & $\begin{array}{r}179 \\
112 \\
35 \\
110 \\
24 \\
31 \\
38\end{array}$ & $\begin{array}{r}22 \\
23 \\
8 \\
38 \\
14 \\
30 \\
46\end{array}$ \\
\hline Total & 501 & 155 & 529 & 181 \\
\hline
\end{tabular}

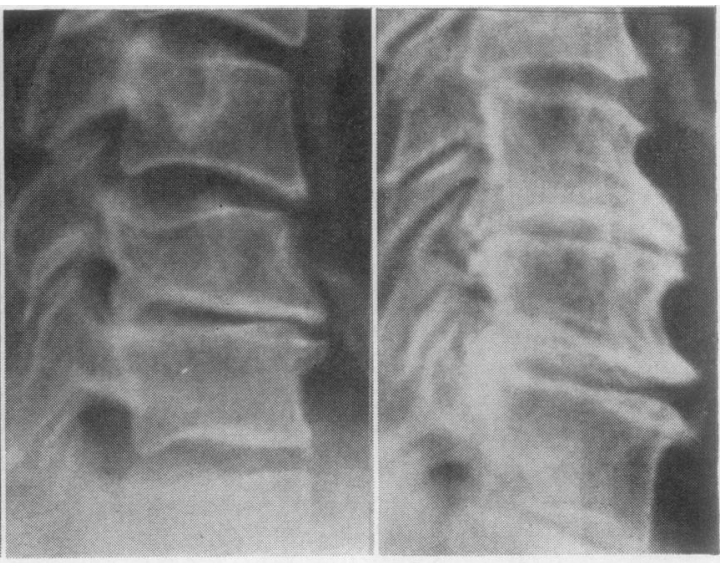

Grade 3. Anterior osteophytes and narrowing of disc
Grade 4. Anterior osteophytes, disc narrowing and sclerosis of vertebral plates

\begin{abstract}
Grade 2. Anterior osteo-
\end{abstract}

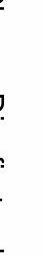




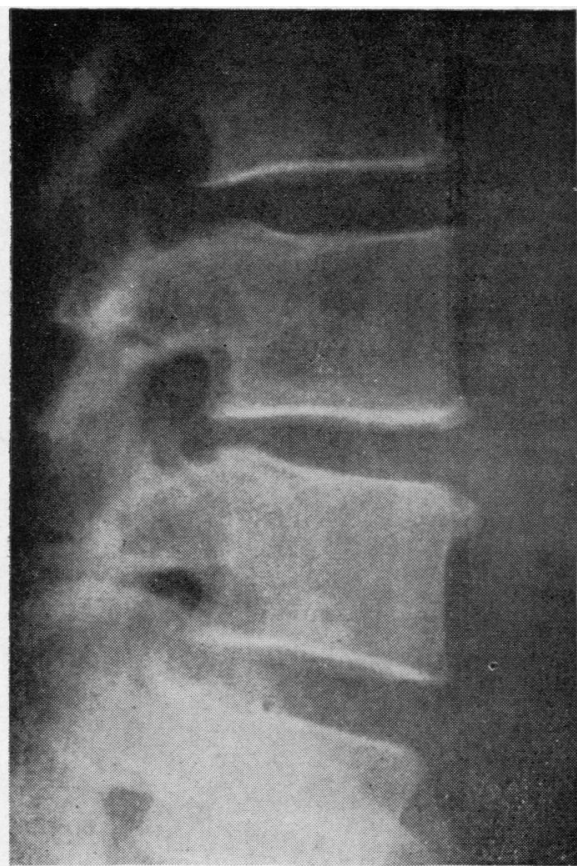

Grade 1. Slight anterior wear and osteophyte formation

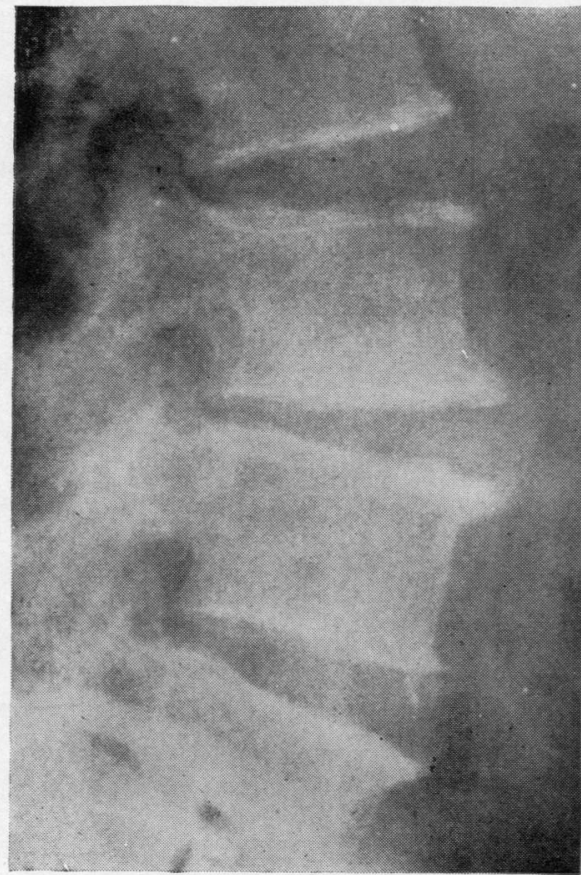

Grade 3. Osteophyte formation and narrowing of disc

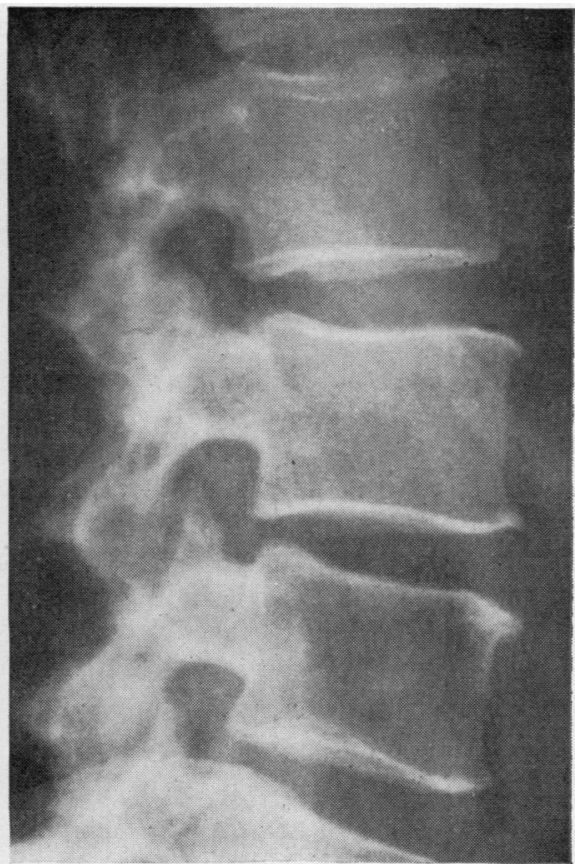

Grade 2. Definite anterior wear and osteophyte formation
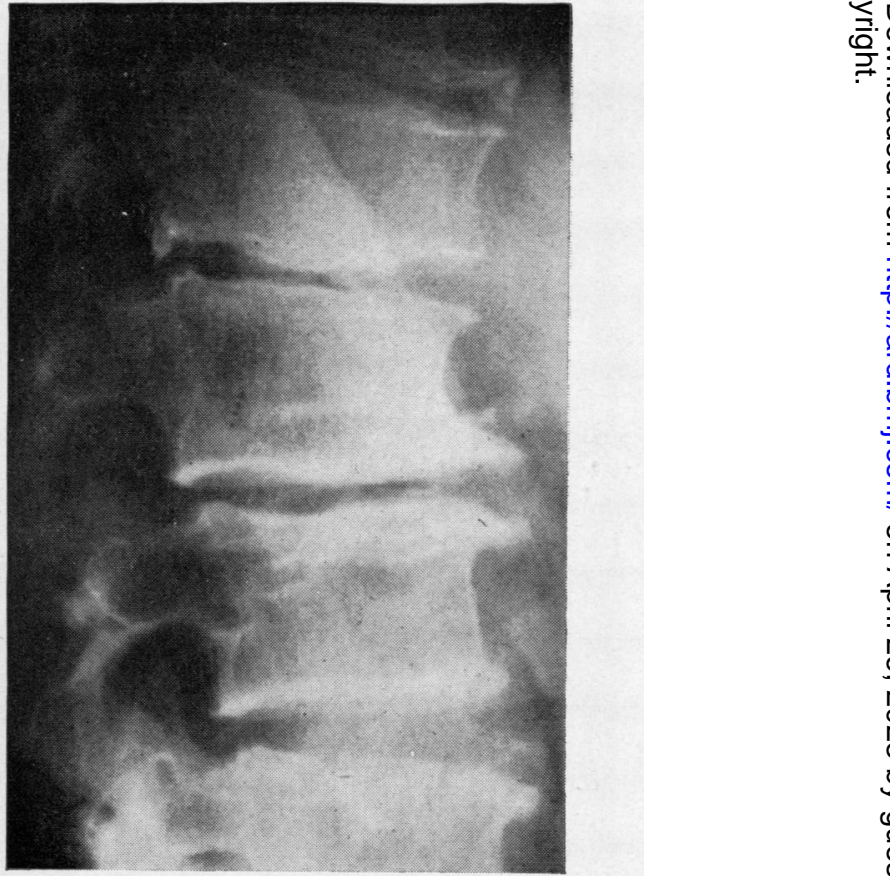

Grade 4. Large osteophytes, marked disc narrowing, sclerosis of vertebral plates, and posterior subluxation

Fig. 2.-Lumbar disc degeneration. 
gave a history of pain in this area at some time in the past. The pain was mainly limited to the shoulder in males and to the neck in females, but both neck and shoulders were affected in a large proportion of both sexes, the pain being thus located in the C4, 5 distribution.

Only about half of the respondents were able to remember when they had first felt the pain. This applied particularly where the pain was no longer present. In those who were able to remember, the incidence of neck-shoulder-brachial pain rose with age in both sexes (Fig. 3). Less than 1 per cent. of those with pain at the time of the survey remembered having pain before the age of 14 , and the incidence rose to 6 per cent. in females at age 60, dropping thereafter. In males it reached a maximum of 11 per cent. in the oldest age group. The incidence of past pain rose to 8 per cent. after age 64 in both sexes. The pain had occurred as a single attack in 49 per cent. and was episodic in 42 per cent., and chronic in 9 per cent.

Back-hip-sciatic pain was present at the time of the survey in 79 (11 per cent.) of the 713 males and in 153 (19 per cent.) of the 809 females aged 35 and over with lumbar spine $x$ rays. In addition, 283 (40 per cent.) of the males and 267 (33 per cent.) of the females gave a history of pain in the past only. In those with pain at the time of the survey the incidence had risen till age 40 in males and then remained constant, but in females it continued to rise up to and over the age of 65 (Fig. 4). Past pain was at its maximum at age 40 to 50 in males and age 50 in females and thereafter declined. The pain was most commonly localized in the low back radiating in a third of the cases to the hip or leg It was episodic in 57 per cent., occurred as a single attack in 29 per cent., and was chronic in 14 per cent.

\section{Prevalence of $X$-Ray Changes}

Cervical Disc Degeneration.-In the combined $\frac{\bar{p}}{\frac{7}{2}}$ adult populations of Leigh, Wensleydale, Watford, $\varrho$ and the Rhondda, the greater prevalence in malesen of radiological evidence of cervical disc degeneration noted in our smaller sample was confirmed. Asdetermined by the unweighted mean of six age $\vec{\omega}$ groups, grade 2-4 change was found in 42 per cent. of males and 37 per cent. of females (Table II and $\bar{\alpha}$ Fig. 5, opposite).

In more than half of these cases the changesi were minimal. Grade 3-4 change was found in 22 per cent. of males and 17 per cent. of females, $\stackrel{-}{-}$ a significant sex difference $(P \simeq 0.05)$ which, how-음 ever, was limited to the older age groups from $55-$ onwards. Up to the age of 54 the prevalence of grade 3-4 changes was much the same in males and females. Grade 2 change showed no obvious sex difference, and it was apparent that the males simplye had more severe changes. They also tended to hagee more discs involved. Four or more discs weqe affected in 6 per cent. of males and 4 per cent. females after correction for age. The present data also confirm the relationship to age noted in ourg earlier study $(\mathrm{P}<0.0005)$.

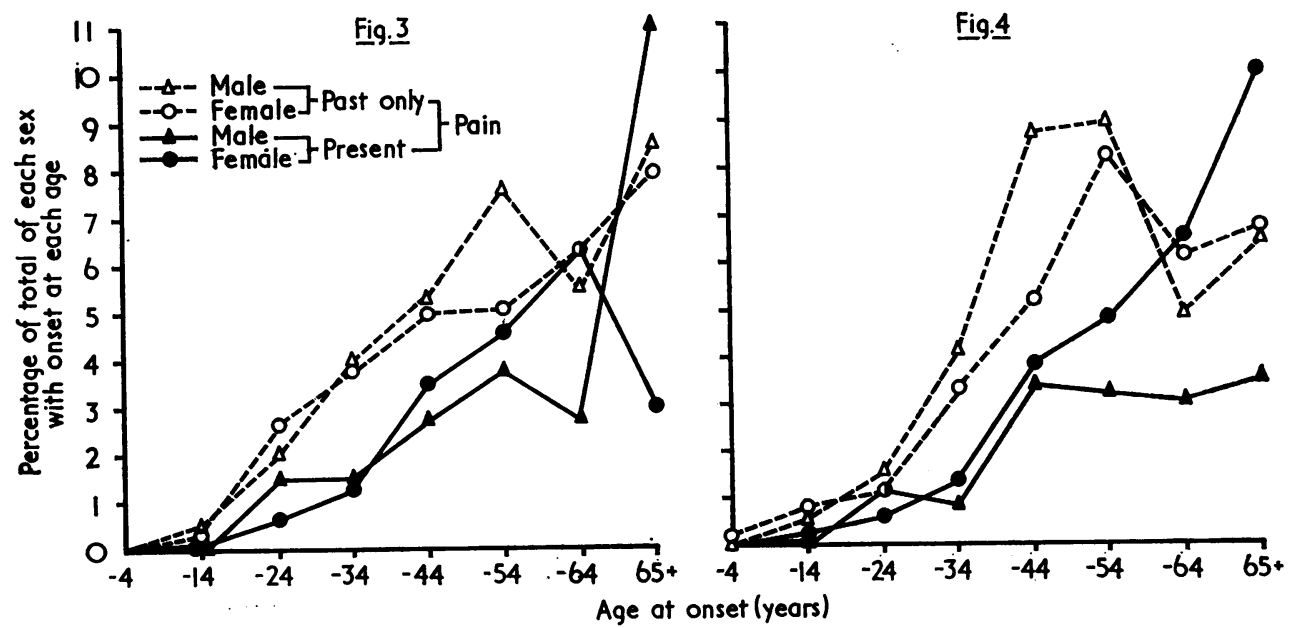

Fig. 3.-Incidence of neck-shoulder-brachial pain, by age and sex.

Fig. 4.-Incidence of back-hip-sciatic pain, by age and sex. 
TABLE II

RADIOLOGICAL EVIDENCE OF DISC DEGENERATION IN CERVICAL SPINE IN LEIGH, WENSLEYDALE, WATFORD, AND RHONDDA, BY SEX AND AGE GROUP

Enlarged Sample

\begin{tabular}{|c|c|c|c|c|c|c|c|c|c|c|c|c|c|c|}
\hline \multirow{3}{*}{$\begin{array}{l}\text { Age } \\
\text { Group } \\
\text { (yrs) }\end{array}$} & \multicolumn{7}{|c|}{ Males } & \multicolumn{7}{|c|}{ Females } \\
\hline & \multirow{2}{*}{$\underset{x \text {-rayed }}{\text { Total }}$} & \multicolumn{5}{|c|}{$\begin{array}{c}\text { Grade of } \\
\text { Disc Degeneration }\end{array}$} & \multirow{2}{*}{$\begin{array}{l}\text { No. with } \\
\text { grade } 1-4 \\
\text { in four or } \\
\text { more discs }\end{array}$} & \multirow{2}{*}{$\underset{x \text {-rayed }}{\text { Total }}$} & \multicolumn{5}{|c|}{$\begin{array}{c}\text { Grade of } \\
\text { Disc Degeneration }\end{array}$} & \multirow{2}{*}{$\begin{array}{l}\text { No. with } \\
\text { grade } 1-4 \\
\text { in four or } \\
\text { more discs }\end{array}$} \\
\hline & & 0 & 1 & 2 & 3 & 4 & & & 0 & 1 & 2 & 3 & 4 & \\
\hline $\begin{array}{r}15-24 \\
-34 \\
-44 \\
-54 \\
-64 \\
65+\end{array}$ & $\begin{array}{l}220 \\
220 \\
377 \\
450 \\
350 \\
186\end{array}$ & $\begin{array}{r}208 \\
185 \\
237 \\
161 \\
80 \\
10\end{array}$ & $\begin{array}{r}9 \\
15 \\
32 \\
42 \\
33 \\
13\end{array}$ & $\begin{array}{r}3 \\
19 \\
82 \\
149 \\
101 \\
48\end{array}$ & $\begin{array}{r}\overline{1} \\
26 \\
93 \\
121 \\
96\end{array}$ & $\begin{array}{r}- \\
\overline{-} \\
\overline{5} \\
15 \\
19\end{array}$ & $\begin{array}{r}- \\
\overline{2} \\
7 \\
36 \\
42\end{array}$ & $\begin{array}{l}205 \\
220 \\
246 \\
265 \\
379 \\
257\end{array}$ & $\begin{array}{r}197 \\
192 \\
177 \\
102 \\
87 \\
42\end{array}$ & $\begin{array}{r}7 \\
18 \\
18 \\
26 \\
36 \\
26\end{array}$ & $\begin{array}{r}1 \\
8 \\
37 \\
72 \\
155 \\
85\end{array}$ & $\begin{array}{l}\overline{2} \\
14 \\
63 \\
95 \\
95\end{array}$ & $\begin{array}{l}- \\
\overline{2} \\
6 \\
9\end{array}$ & $\begin{array}{r}- \\
\overline{-} \\
\overline{7} \\
26 \\
33\end{array}$ \\
\hline Total & 1,803 & 881 & 144 & 402 & 337 & 39 & 87 & 1,572 & 797 & 131 & 358 & 269 & 17 & 66 \\
\hline
\end{tabular}

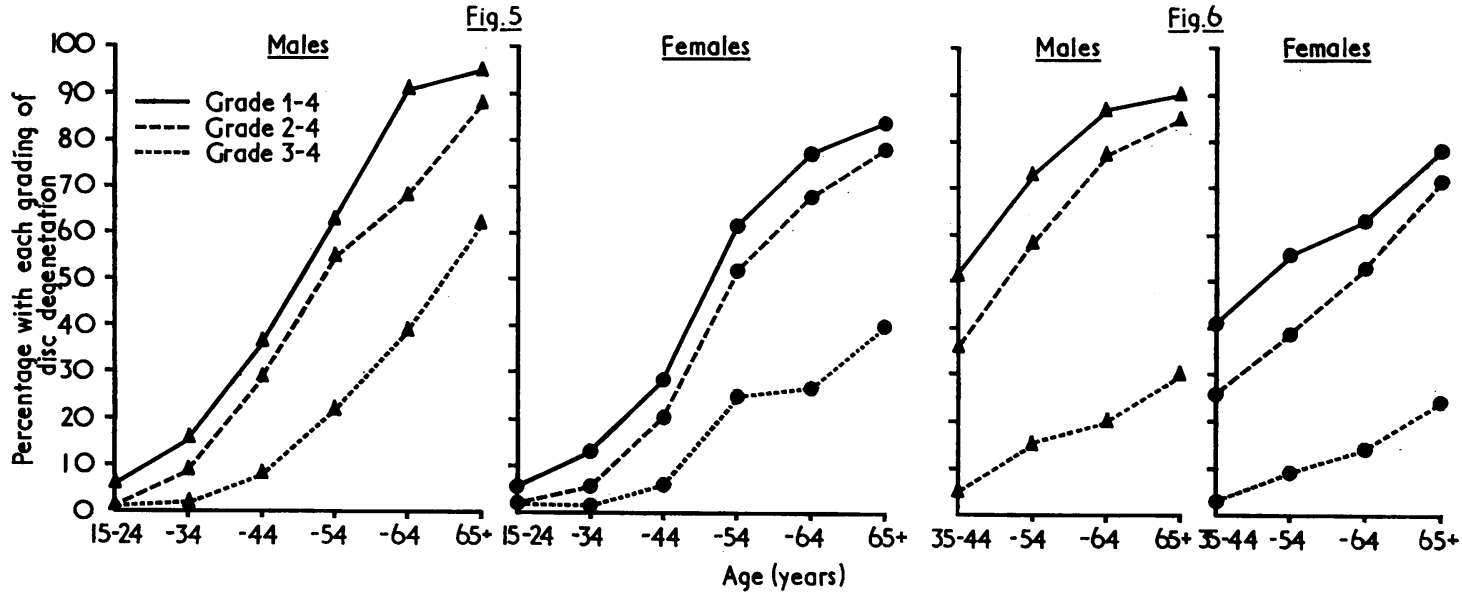

Fig. 5.-Grade of cervical disc degeneration, by age and sex.

Fig. 6.-Grade of lumbar disc degeneration, by age and sex.

Lumbar Disc Degeneration.-The greater prevalence of lumbar disc degeneration in males was also confirmed, and involved the minimal as well as the more severe grades (Table III and Fig. 6). The unweighted mean of four age groups for grade 2-4 disc degeneration was 65 per cent. in males and 52 per cent. in females. The difference, however, was significant only in the more severe grades (3-4) which were present in 20 per cent. of males and 13 per cent. of females $(P \simeq 0 \cdot 01)$. Multiple disc involvement was also significantly more frequent in males; 23 per cent. of males and 9 per cent. of

TABLE III

RADIOLOGICAL EVIDENCE OF DISC DEGENERATION IN LUMBAR SPINE IN LEIGH, WENSLEYDALE, AND WATFORD

Enlarged Sample

\begin{tabular}{|c|c|c|c|c|c|c|c|c|c|c|c|c|c|c|}
\hline \multirow{3}{*}{$\underset{\substack{\text { Group } \\
\text { (yrs) }}}{\text { Age }}$} & \multicolumn{7}{|c|}{ Males } & \multicolumn{7}{|c|}{ Females } \\
\hline & \multirow{2}{*}{$\underset{x \text {-rayed }}{\text { Total }}$} & \multicolumn{5}{|c|}{$\begin{array}{c}\text { Grade of } \\
\text { Disc Degeneration }\end{array}$} & \multirow{2}{*}{$\begin{array}{l}\text { No. with } \\
\text { grade } 1-4 \\
\text { in four or } \\
\text { more discs }\end{array}$} & \multirow{2}{*}{$\underset{x \text {-rayed }}{\text { Total }}$} & \multicolumn{5}{|c|}{$\begin{array}{c}\text { Grade of } \\
\text { Disc Degeneration }\end{array}$} & \multirow{2}{*}{$\begin{array}{l}\text { No. with } \\
\text { grade 1-4 } \\
\text { in four or } \\
\text { more discs }\end{array}$} \\
\hline & & 0 & 1 & 2 & 3 & 4 & & & 0 & 1 & 2 & 3 & 4 & \\
\hline $\begin{array}{c}35-44 \\
-54 \\
-64 \\
65+\end{array}$ & $\begin{array}{l}185 \\
236 \\
154 \\
138\end{array}$ & $\begin{array}{l}90 \\
64 \\
20 \\
12\end{array}$ & $\begin{array}{r}29 \\
33 \\
14 \\
9\end{array}$ & $\begin{array}{r}56 \\
103 \\
89 \\
65\end{array}$ & $\begin{array}{r}9 \\
35 \\
25 \\
44\end{array}$ & $\begin{array}{l}1 \\
1 \\
6 \\
8\end{array}$ & $\begin{array}{r}3 \\
34 \\
56 \\
56\end{array}$ & $\begin{array}{l}211 \\
236 \\
182 \\
180\end{array}$ & $\begin{array}{r}125 \\
104 \\
66 \\
40\end{array}$ & $\begin{array}{l}33 \\
39 \\
19 \\
13\end{array}$ & $\begin{array}{l}47 \\
72 \\
72 \\
84\end{array}$ & $\begin{array}{r}5 \\
19 \\
20 \\
34\end{array}$ & $\begin{array}{l}1 \\
2 \\
5 \\
9\end{array}$ & $\begin{array}{r}4 \\
10 \\
17 \\
35\end{array}$ \\
\hline Total & 713 & 186 & 85 & 313 & 113 & 16 & 149 & 809 & 335 & 104 & 275 & 78 & 17 & 66 \\
\hline
\end{tabular}


females had four or more discs affected $(\mathrm{P}<0.0005$; $\chi^{2}$ 46). This difference between the sexes was present at all ages. As in the case of the cervical spine, the changes increased progressively in frequency and severity with age $(P<0.0005)$. It should be pointed out that individuals with grade. 3-4 disc degeneration nearly always had grade 2 changes in other discs.

\section{Relationship of Radiological Changes to Symptoms}

On the assumption that pain resulting from a degenerate disc would be felt either in the appropriate interspinous ligament or in the segmental distribution as determined by Kellgren (1939) and summarized by Lewis (1942) (Fig. 7), a comparison has been made between $x$-ray changes in various parts of the spine and symptoms in the distribution of the corresponding local and segmental areas.

Cervical Spine.-There was in both sexes a significant increase in symptoms in the neck- shoulder-brachial distribution in those with grade $\underset{\widetilde{D}}{\vec{D}}$ 3-4 disc degeneration in the cervical spine $\left(P<\frac{5}{3}\right.$ 0.01 ) (Table IV, overleaf). In most cases this was not present at the time of the survey, but a history was given of one or more episodes of pain in the past $\vec{\Rightarrow}$ in nearly a third of those with radiological grade 3-4 $\stackrel{0}{+}$ changes. Loss of work from cervico-brachial pain ? occurred in significantly more males with grade $3-4$ 을 degeneration than in those with grade $0-1$ changes. $\frac{\bar{N}}{\vec{D}}$ The at onset of past episodes of neck-shoulder- $\stackrel{\square}{\Omega}$ brachial pain in cases of grade 3-4 disc degeneration was mainly between 45 and 54 years in males and $\vec{\circ}$ from 65 years onwards in females.

Those with grade 2 radiological changes had $\stackrel{\circ}{\rho}$ rather more symptoms than those graded $0-1$, but $\overline{0}$ there was no significant difference between them. N The onset of symptoms in this group occurred in mainly after age 65 in both sexes. Attacks of pain $\vec{N}$ tended to be more prolonged in those with disc degeneration (11 per cent. chronic) than in those $\frac{\text { s }}{3}$ without ( 8 per cent. chronic) $(P \simeq 0.06)$.

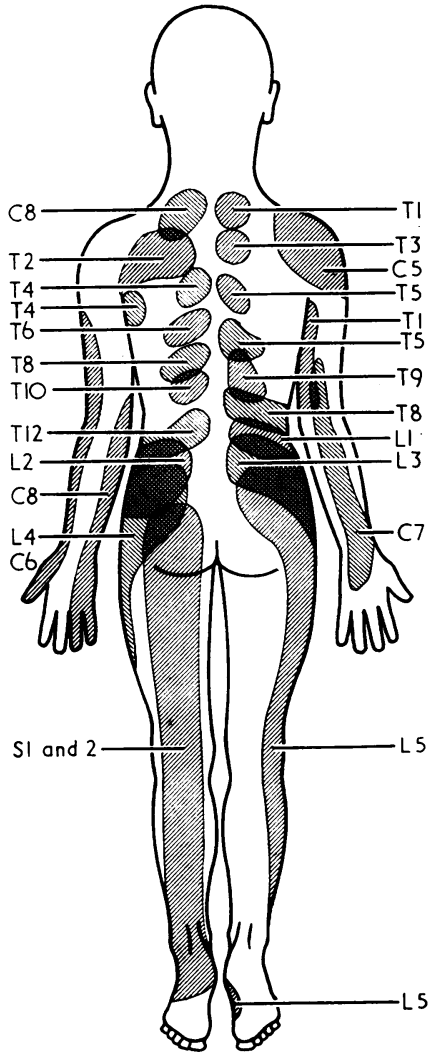

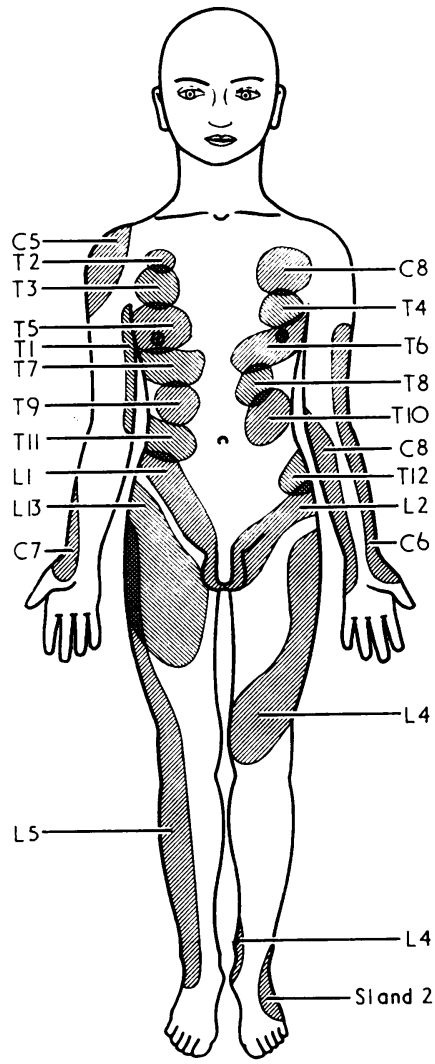


In discussing the relative importance of cervical disc degeneration, other possible causes of pain at these sites must be considered. Shoulder pain may often be due to local causes, and it is not always easy in a retrospective study to separate these from referred pain in the same distribution.

Only 44 males and 38 females had physical signs in the shoulder joint. Except in those with rheumatoid arthritis, the signs were minimal and were in any case more frequent in persons with grade 3-4 disc degeneration. This did not appear to be due to the greater age of those with grade 3-4 change, since it was present after correction for age. It would seem that pain on movement of the shoulders may in some instances have been due to referred tenderness in the shoulder region.

Since neck-shoulder-brachial pain is often due to rheumatoid arthritis, persons having clinical or radiological evidence of this disease in any joint or a positive sheep cell agglutination test (SCAT) were removed from the population samples and the data re-analysed. This resulted in a reduction of the proportion with incapacitating neck-shoulderbrachial pain at all grades of disc degeneration, particularly in females, but did not affect the association between disc degeneration and symptoms.

When rheumatoid arthritis and disc degeneration were both excluded, a history of neck-shoulderbrachial pain was still obtained in 276 males and 252 females. Some of this may have been due to cervical osteoarthrosis, which was shown to be a source of such symptoms in a previous study (Lawrence, Bremner, and Bier, 1966), but when those with grade 0-1 disc degeneration in the nonrheumatoid group were analysed for osteoarthrosis it was found that this accounted for only twelve of the 251 males and eleven of the 221 females. The remainder had been diagnosed mainly as cases of undetermined shoulder pains on clinical examination, and had only mild transient symptoms. Some would no doubt have been diagnosed as cases of capsulitis or shoulder-cuff syndrome if they had been seen during an attack. Whatever the cause of their pain there was no evidence that it increased with age so that osteoarthrosis of the shoulder would be an unlikely cause. Of the thirty males who had lost 3 months or more from work with neckshoulder-brachial pain, only one remained after excluding disc degeneration, rheumatoid arthritis, and osteoarthrosis, and of the 84 males who had lost a week or more of work, only sixteen. The total incapacity rate in males from neck-shoulderbrachial pain was thus reduced from 5 to 2 per cent. Similarly, only two of the 27 females who were severely incapacitated by neck-shoulder-brachial pain remained when those with disc degeneration, rheumatoid arthritis, and osteoarthrosis were deducted and this reduced the total incapacity rate from 6 to 2 per cent. The greatest reduction in both sexes was made by excluding those with "rheumatoid arthritis".

Lumbar Spine.-As in the cervical spine there was a very significant association in males between the symptoms of back-hip-sciatic pain and grade 3-4 $x$-ray changes of disc degeneration in the lumbar spine, and the relationship was to past episodes rather than to pain at the time of the survey, and to incapacitating rather than to trivial pain (Table V, overleaf). Those with grade 2 disc degeneration also had significantly more pain but not more incapacity than those graded $0-1$.

The association between radiological lumbar disc degeneration and symptoms was less striking in females and did not reach accepted levels of significance, largely because of the smaller number with grade 3-4 lumbar disc degeneration. As in the males, those with grade 2 change did not show increased incapacity due to back-hip sciatic pain.

The first episode of pain in males with grade 3-4 lumbar disc degeneration most commonly occurred at about age 50. In females it tended to occur rather later, as would be expected from the slower progression of the disease in this sex. In those with grade 2 disc degeneration, the first episode had occurred at a later age in both sexes, usually after 65. The same tendency to more prolonged pain in those with disc degeneration was observed as in the cervical spine, but owing to the much smaller numbers this was not significant.

As with the neck other causes of back-hip-sciatic pain must be considered.

In some individuals the pain may have been due to hip disease. The hips were $x$-rayed routinely in those aged 55 and over, and osteoarthrosis of the hip was diagnosed radiologically in eighteen of the males in this age range with grade 3-4 lumbar disc degeneration but only four of these had hip pain. Of the 154 males with grade 2 lumbar disc degeneration, 25 had osteoarthrosis of the hip and eight of these had hip pain. Thus in only twelve of the $\mathbf{1 4 0}$ males with symptomatic lumbar disc degeneration could the symptoms have been due to osteoarthrosis of the hip. In fifteen of the 137 females so affected the pain could have been due to osteoarthrosis.

When those with osteoarthrosis of the lumbar spine and "rheumatoid arthritis", as already defined, were excluded from the population samples, the 
RELATIONSHIP OF CERVICO-BRACHIAL PAIQ ]

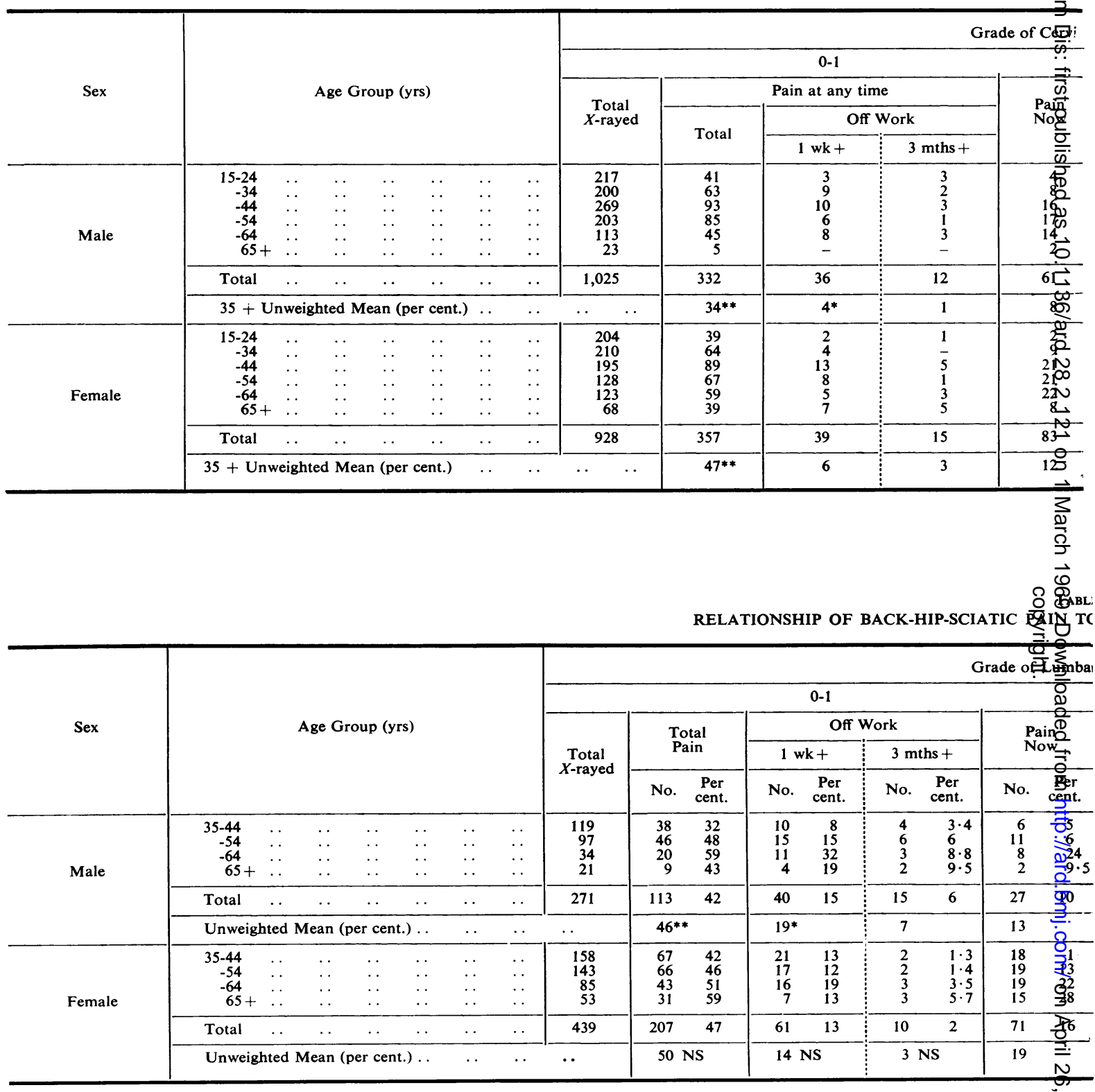

association between disc degeneration and symptoms was much the same as in the total sample. Even in those males without $x$-ray evidence of disc degeneration or osteoarthrosis and without clinical or radiological evidence of rheumatoid arthritis in any joint or positive serology, 50 per cent. had had back-hip-sciatic pain at some time, and 20 per cent. had been incapacitated by it. For females, these proportions were 48 and 14 per cent. respectively. In those who were incapacitated, the most frequent 
C DEGENERATION, BY SEX AND AGE GROUP

\begin{tabular}{|c|c|c|c|c|c|c|c|c|c|}
\hline \multirow{2}{*}{$\underset{X \text {-rayed }}{\text { Total }}$} & \multicolumn{3}{|c|}{ Pain at any time } & \multirow{2}{*}{$\begin{array}{l}\text { Pain } \\
\text { Now }\end{array}$} & \multirow{2}{*}{$\underset{X \text {-rayed }}{\text { Total }}$} & \multicolumn{3}{|c|}{ Pain at any time } & \multirow{2}{*}{$\begin{array}{l}\text { Pain } \\
\text { Now }\end{array}$} \\
\hline & Total & $1 \mathrm{wk}+$ & $3 \mathrm{mths}+$ & & & Total & 1 wk + & 3 mths + & \\
\hline $\begin{array}{r}3 \\
19 \\
82 \\
149 \\
101 \\
48\end{array}$ & $\begin{array}{r}1 \\
5 \\
25 \\
59 \\
34 \\
24\end{array}$ & $\begin{array}{l}-\overline{1} \\
3 \\
7 \\
3 \\
2\end{array}$ & $\begin{array}{l}- \\
\overline{2} \\
3 \\
1 \\
-\end{array}$ & $\begin{array}{r}\overline{1} \\
5 \\
19 \\
9 \\
10\end{array}$ & $\begin{array}{r}\overline{1} \\
26 \\
98 \\
136 \\
115\end{array}$ & $\begin{array}{r}\overline{1} \\
14 \\
44 \\
52 \\
65\end{array}$ & $\begin{array}{r}- \\
\overline{3} \\
12 \\
6 \\
11\end{array}$ & $\begin{array}{l}- \\
\overline{1} \\
2 \\
5 \\
4\end{array}$ & $\begin{array}{r}\overline{-} \\
\overline{2} \\
16 \\
13 \\
19\end{array}$ \\
\hline \multirow[t]{2}{*}{402} & 148 & 16 & 6 & 44 & 376 & 176 & 32 & 12 & 50 \\
\hline & 36 & 4 & $0 \cdot 8$ & 10 & & $59 * *$ & $8 *$ & 3 NS & 8 \\
\hline $\begin{array}{r}1 \\
8 \\
37 \\
72 \\
155 \\
85\end{array}$ & $\begin{array}{r}\overline{4} \\
17 \\
44 \\
69 \\
51\end{array}$ & $\begin{array}{r}- \\
\overline{1} \\
6 \\
13 \\
6\end{array}$ & $\begin{array}{l}- \\
\overline{1} \\
1 \\
3 \\
4\end{array}$ & $\begin{array}{r}- \\
\overline{4} \\
10 \\
28 \\
11\end{array}$ & $\begin{array}{r}\overline{2} \\
14 \\
65 \\
101 \\
104\end{array}$ & $\begin{array}{r}\overline{2} \\
10 \\
42 \\
51 \\
63\end{array}$ & $\begin{array}{r}\overline{-} \\
\overline{2} \\
7 \\
10 \\
7\end{array}$ & $\begin{array}{l}\bar{z} \\
\overline{-} \\
\overline{1} \\
2\end{array}$ & $\begin{array}{r}-\overline{1} \\
1 \\
10 \\
20 \\
13\end{array}$ \\
\hline 358 & 52 & 5 & 2 & 11 & & $69 * *$ & 8 & 0.6 & 11 \\
\hline
\end{tabular}

SC DEGENERATION, BY SEX AND AGE GROUP

sc Degeneration

\begin{tabular}{|c|c|c|c|c|c|c|c|c|c|c|c|c|c|c|c|c|c|}
\hline \multicolumn{9}{|c|}{2} & \multicolumn{9}{|c|}{$3-4$} \\
\hline \multirow{3}{*}{$\underset{X \text {-rayed }}{\text { Total }}$} & \multirow{2}{*}{\multicolumn{2}{|c|}{$\begin{array}{l}\text { Total } \\
\text { Pain }\end{array}$}} & \multicolumn{4}{|c|}{ Off Work } & \multirow{2}{*}{\multicolumn{2}{|c|}{$\begin{array}{l}\text { Pain } \\
\text { Now }\end{array}$}} & \multirow{3}{*}{$\underset{X \text {-rayed }}{\text { Total }}$} & \multirow{2}{*}{\multicolumn{2}{|c|}{$\begin{array}{l}\text { Total } \\
\text { Pain }\end{array}$}} & \multicolumn{4}{|c|}{ Off Work } & \multirow{2}{*}{\multicolumn{2}{|c|}{$\begin{array}{l}\text { Pain } \\
\text { Now }\end{array}$}} \\
\hline & & & \multicolumn{2}{|c|}{$1 \mathbf{w k}+$} & \multicolumn{2}{|c|}{$3 \mathrm{mths}+$} & & & & & & \multicolumn{2}{|c|}{$1 \mathrm{wk}+$} & \multicolumn{2}{|c|}{3 mths +} & & \\
\hline & No. & $\begin{array}{c}\text { Per } \\
\text { cent. }\end{array}$ & No. & $\begin{array}{l}\text { Per } \\
\text { cent. }\end{array}$ & No. & $\begin{array}{c}\text { Per } \\
\text { cent. }\end{array}$ & No. & $\begin{array}{l}\text { Per } \\
\text { cent. }\end{array}$ & & No. & $\begin{array}{c}\text { Per } \\
\text { cent. }\end{array}$ & No. & $\begin{array}{c}\text { Per } \\
\text { cent. }\end{array}$ & No. & $\begin{array}{c}\text { Per } \\
\text { cent. }\end{array}$ & No. & $\begin{array}{c}\text { Per } \\
\text { cent. }\end{array}$ \\
\hline $\begin{array}{r}56 \\
103 \\
89 \\
65\end{array}$ & $\begin{array}{l}27 \\
51 \\
55 \\
35\end{array}$ & $\begin{array}{l}48 \\
49 \\
62 \\
54\end{array}$ & $\begin{array}{r}6 \\
17 \\
20 \\
11\end{array}$ & $\begin{array}{l}11 \\
16 \cdot 5 \\
22 \\
17\end{array}$ & $\begin{array}{l}3 \\
6 \\
6 \\
3\end{array}$ & $\begin{array}{l}5 \cdot 4 \\
5 \cdot 8 \\
7 \\
4 \cdot 6\end{array}$ & $\begin{array}{r}5 \\
13 \\
12 \\
7\end{array}$ & $\begin{array}{r}9 \\
13 \\
14 \\
11\end{array}$ & $\begin{array}{l}10 \\
36 \\
31 \\
52\end{array}$ & $\begin{array}{r}6 \\
25 \\
22 \\
28\end{array}$ & $\begin{array}{l}60 \\
69 \\
71 \\
54\end{array}$ & $\begin{array}{r}3 \\
13 \\
8 \\
14\end{array}$ & $\begin{array}{l}30 \\
36 \\
26 \\
27\end{array}$ & $\begin{array}{l}\overline{5} \\
3 \\
5\end{array}$ & $\begin{array}{c}0 \\
14 \\
10 \\
9.6\end{array}$ & $\begin{array}{l}\overline{6} \\
2 \\
7\end{array}$ & $\begin{array}{r}0 \\
17 \\
6 \\
12\end{array}$ \\
\hline \multirow[t]{2}{*}{313} & 168 & 54 & 54 & 17 & 18 & 6 & 37 & 12 & 129 & 81 & 63 & 38 & 29 & 13 & 10 & 15 & 12 \\
\hline & 53 & & 17 & & 6 & & 12 & & & $64 * *$ & & $30^{*}$ & & 9 & & 9 & \\
\hline $\begin{array}{l}47 \\
72 \\
72 \\
84\end{array}$ & $\begin{array}{l}21 \\
39 \\
40 \\
51\end{array}$ & $\begin{array}{l}45 \\
54 \\
56 \\
61\end{array}$ & $\begin{array}{r}6 \\
4 \\
6 \\
14\end{array}$ & $\begin{array}{c}13 \\
5 \cdot 6 \\
8 \cdot 4 \\
17\end{array}$ & $\begin{array}{l}0 \\
2 \\
5\end{array}$ & $\begin{array}{l}0 \\
0 \\
2 \cdot 8 \\
5.9\end{array}$ & $\begin{array}{r}7 \\
14 \\
12 \\
19\end{array}$ & $\begin{array}{l}15 \\
19 \cdot 5 \\
17 \\
23\end{array}$ & $\begin{array}{r}6 \\
21 \\
25 \\
43\end{array}$ & $\begin{array}{r}2 \\
14 \\
14 \\
32\end{array}$ & $\begin{array}{l}33 \\
67 \\
54 \\
75\end{array}$ & $\begin{array}{l}2 \\
4 \\
6 \\
7\end{array}$ & $\begin{array}{l}33 \\
19 \\
24 \\
16\end{array}$ & $\begin{array}{l}1 \\
\overline{1} \\
4\end{array}$ & $\begin{array}{c}17 \\
0 \\
4 \\
9 \cdot 4\end{array}$ & $\begin{array}{r}1 \\
5 \\
5 \\
19\end{array}$ & $\begin{array}{l}17 \\
24 \\
20 \\
45\end{array}$ \\
\hline \multirow[t]{2}{*}{275} & 151 & 55 & 30 & 11 & 7 & 3 & 52 & 19 & 95 & 62 & 65 & 19 & 20 & 6 & 6 & 30 & 32 \\
\hline & 54 & & 11 & & 2 & & 19 & & & $58 \mathrm{r}$ & & 23 & & 61 & & 27 & \\
\hline
\end{tabular}

clinical diagnoses were disc prolapse and spondylitis, but the majority were labelled lumbar-sciatic pain of undetermined origin. Whether these had degenerative changes in the intervertebral discs which were not discernible radiologically, it is impossible to decide on the evidence available in field surveys. Flexion-extension pictures were not taken in these surveys, so that the amount of slip occurring at the lumbar discs could not be measured, but in a previous survey in miners in which such 
measurements were made, these radiographs showed little which was not revealed by the flexion view, such as was used in these surveys. Slight degrees of subluxation were found in the lumbar spine in only two of the 195 males and two of the 272 females without disc degeneration, osteoarthrosis, or rheumatoid arthritis. Three of these had had lumbar or sciatic pain, but none had been incapacitated. Of those with grade 3-4 lumbar disc degeneration, nine had subluxation, and five of these had back-hipsciatic pain. There was thus no evidence that the subluxations were responsible for the symptoms.

\section{Clinical Disc Degeneration}

A clinical diagnosis of disc degeneration was frequently made during the course of these surveys, and it is of interest to know to what extent this was confirmed by radiological evidence. In Table VI the clinical and radiological diagnoses of cervical disc degeneration are compared. The clinical gradings were on the whole lower than those made from the radiographs. Only half of those with radiological grade 4 change were diagnosed on clinical grounds of those 36 per cent. with grade 3 radiological change, 20 per cent. with grade 2,14 per cent. with grade 1 , and 7 per cent. with grade 0 . Thus most of those with radiological evidence of disc degeneration were not detected clinically. On the other hand, those in whom a clinical diagnosis of disc degeneration (grade 2-4) was made nearly all showed radiological evidence. The correlation coefficient $(r=0.52)$ is thirty times the standard error, and is highly significant.

Lumbar disc degeneration showed a less satisfactory correlation between the radiological and clinical diagnosis $(r=0 \cdot 16)$.

\section{Relationship of Cervical to Lumbar Disc Degeneration}

If disc degeneration is a constitutional disorder, a relationship between cervical and lumbar disc degeneration involvement would be expected regardless of age or sex. In fact there was a very significant relationship in both sexes (Table VII). Those with grade 3-4 cervical disc degeneration had two to three times more grade 3-4 lumbar changes. Males had on the whole more frequent and more severe changes in the lumbar spine in relation to each grade of cervical disc degeneration, which suggests that environmental and possibly occupational causes play a more important part in men.

\section{Relationship of Disc Degeneration to Congenital and Other Abnormalities}

The most frequent congenital abnormalities were spondylolisthesis in the lumbar and block vertebra in the cervical spine. Spondylolisthesis was present in nineteen males and eight females. Of these 27 individuals, 26 had disc degeneration affecting particularly the disc below the affected vertebra. Block vertebra was present in 23 males and six

TABle VI

LEIGH, WENSLEYDALE, WATFORD, AND RHONDDA

CLINICAL COMPARED WITH RADIOLOGICAL DISC DEGENERATION OF THE CERVICAL SPINE, BY SEX

\begin{tabular}{|c|c|c|c|c|c|c|c|c|c|c|c|c|}
\hline \multirow{3}{*}{$\begin{array}{c}\text { Clinical } \\
\text { Grade } \\
\text { of } \\
\text { Disc } \\
\text { Degeneration }\end{array}$} & \multicolumn{6}{|c|}{ Males } & \multicolumn{6}{|c|}{ Females } \\
\hline & \multirow{2}{*}{ Total } & \multicolumn{5}{|c|}{ Radiological Grade } & \multirow{2}{*}{ Total } & \multicolumn{5}{|c|}{ Radiological Grade } \\
\hline & & 0 & 1 & 2 & 3 & 4 & & $\mathbf{0}$ & 1 & 2 & 3 & 4 \\
\hline $\begin{array}{l}4 \\
3 \\
2 \\
1 \\
0\end{array}$ & $\begin{array}{r}7 \\
83 \\
208 \\
237 \\
1,268\end{array}$ & $\begin{array}{r}\overline{7} \\
49 \\
99 \\
726 \\
\end{array}$ & $\begin{array}{r}2 \\
5 \\
12 \\
25 \\
100\end{array}$ & $\begin{array}{r}1 \\
21 \\
59 \\
62 \\
259\end{array}$ & $\begin{array}{r}4 \\
45 \\
77 \\
47 \\
164\end{array}$ & $\begin{array}{r}- \\
5 \\
11 \\
4 \\
19\end{array}$ & $\begin{array}{r}2 \\
57 \\
180 \\
270 \\
1,063\end{array}$ & $\begin{array}{r}\overline{6} \\
50 \\
126 \\
615 \\
\end{array}$ & $\frac{\overline{7}}{\frac{11}{24}}$ & $\begin{array}{r}1 \\
18 \\
52 \\
66 \\
221\end{array}$ & $\begin{array}{r}1 \\
24 \\
64 \\
50 \\
130\end{array}$ & $\begin{array}{l}- \\
2 \\
3 \\
4 \\
8\end{array}$ \\
\hline Total & 1,803 & 881 & 144 & 402 & 337 & 39 & 1,572 & 797 & 131 & 358 & 269 & 17 \\
\hline
\end{tabular}

TABLE VII

PERCENTAGE RELATIONSHIP OF CERVICAL TO LUMBAR DISC DEGENERATION IN LEIGH, WENSLEYDALE, AND WATFORD (UNWEIGHTED MEAN OF FOUR AGE GROUPS FROM 35-64 AND $65+$ ), BY SEX

\begin{tabular}{|c|c|c|c|c|c|c|}
\hline \multirow{3}{*}{$\begin{array}{l}\text { Grade of Cervical } \\
\text { Disc Degeneration }\end{array}$} & \multicolumn{3}{|c|}{ Males } & \multicolumn{3}{|c|}{ Females } \\
\hline & \multirow{2}{*}{ Total No. } & \multicolumn{2}{|c|}{ Grade of Lumbar Disc Degeneration } & \multirow{2}{*}{ Total No. } & \multicolumn{2}{|c|}{ Grade of Lumbar Disc Degeneration } \\
\hline & & $2-4$ & $3-4$ & & $2-4$ & $3-4$ \\
\hline $\begin{array}{c}3-4 \\
2 \\
1 \\
0\end{array}$ & $\begin{array}{r}234 \\
158 \\
65 \\
233\end{array}$ & $\begin{array}{l}66 * * * \\
72 \\
59 \\
49 * * *\end{array}$ & $\begin{array}{l}24^{* *} \\
18 \\
14 \\
13^{* *}\end{array}$ & $\begin{array}{r}204 \\
227 \\
72 \\
304\end{array}$ & $\begin{array}{l}56^{* *} \\
46 \\
44 \\
36^{* *}\end{array}$ & $\begin{array}{l}16^{* *} \\
14 \\
13 \\
6 * *\end{array}$ \\
\hline
\end{tabular}


females. Only fifteen had cervical disc degeneration, which in four cases was grade 3 or more. This is roughly the expected number in such a population. The disc degeneration was not usually related to the site of the block vertebra, the affected discs being usually $C 5$ and 6 regardless of the site of the block. Schmorl's nodes were associated with disc degeneration rather more often than expected, but this may well have been occupational, since both conditions are more common in heavy manual workers.

\section{Relationship of Disc Degeneration to Occupation (Table VIII)}

Cervical.-The greatest prevalence of disc degeneration in this region was found in the miscellaneous manual workers, who had significantly more than the outdoor workers or those in light or medium industry. The business and professional workers also had significantly more than these last two groups. The more severe changes, however, were encountered mainly in coal miners who had significantly more grade 3-4 change than those in trade or in light and medium industry or in outdoor work. The females showed no significant occupational differences. Where males and females followed the same occupation they tended to have the same prevalence of degeneration. The exception to this was the textile workers. The male textile workers had significantly more grade 3-4 change than the females. This may, however, have been occupational, since the males were mainly spinners and the females tenters (machine tenders) or weavers.

Lumbar.-Disc degeneration in the lumbar region was most frequent in coal miners, but the prevalence was also high in outdoor workers (Table IX, overleaf).

These two groups had significantly more than the business or professional or textile workers. The miscellaneous manual workers and those in heavy industry also had a high prevalence of lumbar disc degeneration, but the numbers whose lumbar spines were $x$-rayed were small in these groups. In coalminers and also in outdoor and miscellaneous manual workers the disease started at an earlier age. The most severe changes were found in the outdoor workers. There were no significant differences between the occupational groups in females (Table IX).

\section{Damp Housing}

Information is available on housing conditions only in Leigh and Wensleydale. A total of 56 males and 63 females in Leigh and Wensleydale lived in houses which were considered by the local sanitary officers to be very damp, i.e. having defective subsoil drainage or structural defects.

Damp as so defined was without significant effect on symptomatology in those with or without disc degeneration.

\section{Neurological Complications}

The neurological complications of spondylosis have attracted considerable attention, particularly those in the cervical region involving the spinal cord (Spillane and Lloyd, 1951). Pallis, Jones, and Spillane (1954), in a study of fifty medical or surgical hospital in-patients over the age of 50, found narrowing of the spinal canal due to various combinations of posterior osteophytosis, subluxation of cervical vertebrae, and loss of cervical lordosis in 75 per cent. Some 50 per cent. of the patients with narrowing had physical signs suggestive of cord involvement, including impaired vibration sense in the lower limbs, extensor plantar response, and exaggerated lower limb reflexes. In most instances these signs were not associated with symptoms. They were not found in those without canal narrowing. Foraminal

TABle VIII

PERCENTAGE CERVICAL DISC DEGENERATION, BY SEX AND PREDOMINANT OCCUPATIONS (UNWEIGHTED MEANS)

\begin{tabular}{|c|c|c|c|c|c|c|}
\hline \multirow{3}{*}{ Occupation } & \multicolumn{3}{|c|}{ Males } & \multicolumn{3}{|c|}{ Females } \\
\hline & \multirow{2}{*}{ Total No. } & \multicolumn{2}{|c|}{ Grade } & \multirow{2}{*}{ Total No. } & \multicolumn{2}{|c|}{ Grade } \\
\hline & & $2-4$ & $3-4$ & & $2-4$ & $3-4$ \\
\hline $\begin{array}{l}\text { Miscellaneous Manual } \\
\text { Textile Workers } \\
\text { Business and Professional } \\
\text { Heavy Industry } \\
\text { Miners } \\
\text { Trade } \\
\text { Light and Medium Industry } \\
\text { Outdoor and Armed Forces } \\
\text { Domestic }\end{array}$ & $\begin{array}{r}78 \\
68 \\
172 \\
26 \\
424 \\
230 \\
215 \\
536 \\
-\end{array}$ & $\begin{array}{l}54 * * \\
49 \\
48 * * \\
47 \\
42 \\
44 \\
38 \\
38 \\
\end{array}$ & $\begin{array}{l}32 \\
30 \\
22 \\
21 \\
33 * * \\
20 \\
23 \\
20 \\
\end{array}$ & $\begin{array}{r}2 \overline{202} \\
139 \\
- \\
100 \\
73 \\
17 \\
995\end{array}$ & $\begin{array}{l}\overline{37} \\
40 \\
\overline{-} \\
41 \\
39 \\
8 \\
36\end{array}$ & $\begin{array}{l}\overline{17} \\
21 \\
\overline{21} \\
\overline{12} \\
\overline{16}\end{array}$ \\
\hline
\end{tabular}


TABLE IX

OCCUPATION AND PERCENTAGE LUMBAR DISC DEGENERATION, BY SEX AND AGE GROUP ABOVE 35 YEARS

\begin{tabular}{|c|c|c|c|c|c|c|c|c|c|c|c|c|}
\hline \multirow[t]{2}{*}{ Sex } & \multirow{2}{*}{$\begin{array}{c}\text { Age (yrs) } \\
\text { and Occupation }\end{array}$} & \multirow[t]{2}{*}{ Total } & \multicolumn{2}{|c|}{$\begin{array}{c}\text { Grade } \\
\text { (per cent.) }\end{array}$} & \multirow{2}{*}{$\begin{array}{c}\text { Age (yrs) } \\
\text { and Occupation }\end{array}$} & \multirow[t]{2}{*}{ Total } & \multicolumn{2}{|c|}{$\begin{array}{c}\text { Grade } \\
\text { (per cent.) }\end{array}$} & \multirow{2}{*}{$\begin{array}{c}\text { Age (yrs) } \\
\text { and Occupation }\end{array}$} & \multirow[t]{2}{*}{ Total } & \multicolumn{2}{|c|}{$\begin{array}{c}\text { Grade } \\
\text { (per cent.) }\end{array}$} \\
\hline & & & $2-4$ & $3-4$ & & & $2-4$ & $3-4$ & & & $2-4$ & $3-4$ \\
\hline \multirow{6}{*}{ Male } & $\begin{array}{c}\text { Manual Workers } \\
\text { (Misc.) } \\
35-44 \\
-54 \\
-64 \\
65+\end{array}$ & $\begin{array}{r}12 \\
15 \\
3 \\
5\end{array}$ & $\begin{array}{r}42 \\
40 \\
100 \\
100\end{array}$ & $\begin{array}{r}0 \\
13 \\
33 \\
20\end{array}$ & $\begin{array}{l}\text { Trade } \\
\qquad \begin{array}{r}35-44 \\
-54 \\
-64 \\
65+\end{array}\end{array}$ & $\begin{array}{l}21 \\
27 \\
16 \\
19\end{array}$ & $\begin{array}{l}16 \\
67 \\
75 \\
79\end{array}$ & $\begin{array}{r}3 \\
19 \\
25 \\
32\end{array}$ & $\begin{array}{l}\text { Light and } \\
\text { Medium Industry } \\
\begin{array}{c}35-44 \\
-54 \\
-64 \\
65+\end{array}\end{array}$ & $\begin{array}{l}16 \\
24 \\
19 \\
11\end{array}$ & $\begin{array}{r}25 \\
38 \\
89 \\
100\end{array}$ & $\begin{array}{r}0 \\
4 \\
21 \\
36\end{array}$ \\
\hline & Total & 35 & 71 & 17 & Total & 83 & 59 & 20 & Total & 70 & 63 & 15 \\
\hline & $\begin{array}{l}\text { Heavy } \\
\text { Industry } \\
35-44 \\
-54 \\
-64 \\
65+\end{array}$ & $\begin{array}{l}3 \\
3 \\
2 \\
2\end{array}$ & $\begin{array}{r}33 \\
33 \\
100 \\
100\end{array}$ & $\begin{array}{l}0 \\
0 \\
0 \\
0\end{array}$ & $\begin{array}{l}\text { Outdoor and } \\
\text { Forces } \\
\begin{array}{r}35-44 \\
-54 \\
-64 \\
65+\end{array}\end{array}$ & $\begin{array}{l}81 \\
79 \\
49 \\
46\end{array}$ & $\begin{array}{l}40 \\
72 \\
76 \\
83\end{array}$ & $\begin{array}{l}10 \\
19 \\
29 \\
46\end{array}$ & $\begin{array}{c}\text { Business and } \\
\text { Professional } \\
35-44 \\
-54 \\
-64 \\
65+\end{array}$ & $\begin{array}{l}14 \\
24 \\
20 \\
12\end{array}$ & $\begin{array}{l}14 \\
42 \\
65 \\
75\end{array}$ & $\begin{array}{r}0 \\
4 \\
15 \\
33\end{array}$ \\
\hline & Total & 10 & 67 & 0 & Total & 255 & 68 & 26 & Total & 70 & $49^{* *}$ & 13 \\
\hline & $\begin{array}{l}\text { Textile } \\
\text { Workers } \\
35-44 \\
-54 \\
-64 \\
65+\end{array}$ & $\begin{array}{r}12 \\
15 \\
9 \\
13\end{array}$ & $\begin{array}{l}33 \\
27 \\
67 \\
85\end{array}$ & $\begin{array}{r}0 \\
0 \\
11 \\
15\end{array}$ & $\begin{array}{l}\text { Miners } \\
\qquad \begin{array}{r}35-44 \\
-54 \\
-64 \\
65+\end{array}\end{array}$ & $\begin{array}{l}26 \\
49 \\
36 \\
28\end{array}$ & $\begin{array}{l}50 \\
67 \\
83 \\
89\end{array}$ & $\begin{array}{r}4 \\
24 \\
11 \\
46\end{array}$ & & & & \\
\hline & Total & 49 & $53^{*}$ & 7 & Total & 139 & 72 & 21 & & & & \\
\hline \multirow{4}{*}{ Female } & $\begin{array}{l}\text { Trade } \\
\qquad \begin{array}{r}35-44 \\
-54 \\
-64 \\
65+\end{array}\end{array}$ & $\begin{array}{r}10 \\
16 \\
7 \\
0\end{array}$ & $\begin{array}{l}40 \\
25 \\
71 \\
-\end{array}$ & $\begin{array}{r}0 \\
6 \\
43 \\
\end{array}$ & $\begin{array}{l}\text { Light and } \\
\text { Medium Industry } \\
\begin{array}{c}35-44 \\
-54 \\
-64 \\
65+\end{array}\end{array}$ & $\begin{array}{r}8 \\
14 \\
3 \\
1\end{array}$ & $\begin{array}{r}0 \\
50 \\
67 \\
0\end{array}$ & $\begin{array}{r}0 \\
21 \\
33 \\
0\end{array}$ & $\begin{array}{l}\text { Outdoor and } \\
\text { Forces } \\
\begin{array}{r}35-44 \\
-54 \\
-64 \\
65+\end{array}\end{array}$ & $\begin{array}{l}1 \\
2 \\
0 \\
3\end{array}$ & $\begin{array}{r}0 \\
0 \\
100\end{array}$ & $\begin{array}{c}0 \\
0 \\
67\end{array}$ \\
\hline & Total & 33 & 45 & 16 & Total & 26 & 29 & 14 & Total & 6 & 33 & 17 \\
\hline & 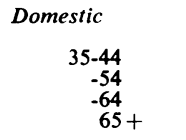 & $\begin{array}{l}133 \\
135 \\
142 \\
159\end{array}$ & $\begin{array}{l}29 \\
41 \\
51 \\
69\end{array}$ & $\begin{array}{r}3 \\
10 \\
12 \\
24\end{array}$ & $\begin{array}{c}\text { Business and } \\
\text { Professional } \\
35-44 \\
-54 \\
-64 \\
65+\end{array}$ & $\begin{array}{r}16 \\
11 \\
8 \\
4\end{array}$ & $\begin{array}{r}31 \\
45 \\
63 \\
100\end{array}$ & $\begin{array}{r}6 \\
9 \\
0 \\
25\end{array}$ & $\begin{array}{l}\text { Textile } \\
\begin{aligned} 35-44 \\
-54 \\
-64 \\
65+\end{aligned}\end{array}$ & $\begin{array}{l}40 \\
56 \\
20 \\
11\end{array}$ & $\begin{array}{l}15 \\
34 \\
60 \\
82\end{array}$ & $\begin{array}{r}3 \\
4 \\
20 \\
18\end{array}$ \\
\hline & Total & 569 & 48 & 8 & Total & 39 & 60 & 10 & Total & 127 & 48 & 11 \\
\hline
\end{tabular}

narrowing was found in 72 per cent. of cases. Root signs were found in 39 per cent. of those with foraminal narrowing but in only 6 per cent. of the remainder. They consisted only of reflex anomalies in the upper limbs. It has been found that the original dimensions of the spinal canal play an important part (Payne and Spillane, 1957; Chrispin and Lees, 1963). According to Brain (1954), cervical myelopathy secondary to spondylosis is the most frequent disease of the spinal cord during and after middle life. Patients with midline protrusions in the floor of a narrow cervical canal may display primary involvement of the cord without involvement of nerve roots. When a spine or ridge intrudes into the foraminal area, lower motor neurone signs with atrophy of the hands suggest amyotrophic lateral sclerosis. Sometimes only the foramina may be narrowed with disability restricted to the upper limbs (Epstein, Epstein, and Lavine, 1963).
Myelopathy may result from direct compression of the cord by a prolapsed disc or, as suggested by Greenfield (1953), from interference with blood flow in the anterior spinal and radicular arteries and veins.

The syndrome of weakness and wasting in the upper limbs combined with spastic weakness of the lower limbs, which has been described in these forms of myelopathy, was not encountered in any of the 662 persons with moderate or severe cervical disc degeneration in the populations under consideration. One woman with grade 3 degeneration of C5, 6, and 7 had bilateral foot drop with weakness of the legs and absent reflexes in the arms and legs, but she also had bilateral ptosis and had been diagnosed at the local hospital as suffering from polyneuritis. One man with grade 4 degeneration of C3-6 had spastic paralysis of the left arm and leg with an extensor plantar response on the left side. 
This was of sudden onset and was attributed to cerebral infarct. One male without cervical disc degeneration gave a history of left hemianaesthesia following a stroke and had spastic legs with exaggerated reflexes and extensor plantar responses.

A history or signs suggestive of cervical neuronal involvement such as paraesthesiae, numbness, or weakness with diminished deep reflexes in the upper limb was found in six of the 1,953 persons with grade $0-1$ disc degeneration in the cervical spine, in three of the 760 with minimal disc degeneration (one of whom had wasting of the small muscles of the hands suggesting anterior horn cell degeneration), and in eleven of the 662 persons with moderate or severe disease. Thus the prevalence of neurological symptoms rose from $0 \cdot 3$ to $1 \cdot 7$ per cent. with increasing severity of disc changes. A history suggestive of pressure on the lumbar nerve roots (usually acute sciatica with or without weakness and paraesthesiae or objective sensory loss, absent ankle or knee jerks, or muscle wasting) was noted in 29 (4 per cent.) of the 710 with grade 0-1 lumbar disc degeneration, in 29 (6 per cent.) of the 528 with minimal disease, and in 22 (10 per cent.) of the 224 with moderate or severe disease. Thus symptoms or signs of nerve root involvement were significantly more common in those with moderate or severe disease as determined radiologically $(P<0.01)$. Neurological signs present at the time of examination, however, were found in only 2 per cent. of those with no or minimal lumbar disc degeneration, and in 5 per cent. of those with moderate or severe disc degeneration. Since only the knee and ankle jerks were routinely tested in our surveys, it was not surprising that a lower prevalence of neuronal and spinal cord involvement was deduced than Pallis and others (1954) recorded. Limitation of straight leg raising was encountered in only two instances and was not of severe degree. None of these persons was seen during the acute stage.

\section{Discussion}

This study confirms that both the minimal grades of disc degeneration, characterized by osteophyte formation without disc narrowing, and the more severe grades, in which the disc is narrowed, increase progressively with age. This appears to contradict the conclusions reached by Caplan and others (1966) that disc narrowing is unrelated to age. It should be pointed out, however, that we took disc narrowing into account only when associated with osteophyte formation. This excluded, for example, most instances of narrowing of L5. Caplan and his colleagues found an increased prevalence of spurring with age but did not consider it to be always associated with disc degeneration. This, of course, can only be determined by pathological studies. Frykholm (1951) divided osteophytes found on vertebral bodies into two groups:

(1) Ventral spurs in the thoraco-lumbar region, not necessarily associated with disc narrowing, and due (according to Schmorl, 1929) to strain on the longtitudinal ligament;

(2) Marginal lipping, either localized or affecting the entire circumference, which he considered to occur only if disc degeneration were present. This was found in all parts of the spine.

The difference, however, is not clear, and it would appear that either type is probably associated with degenerative change in the discs and that it is the bulging of the disc or the abnormal gliding movement, permitted by disc degeneration in the early stages, which strains the ligamentous attachments.

Our study gives some indication of the aetiological factors involved in disc degeneration. Though it may be secondary to other disorders of the spine, such as adolescent kyphosis or scoliosis, old tuberculosis, spondylolysis, or spondylolisthesis, in the great majority of affected individuals there is no local predisposing factor.

A constitutional factor predisposing to an early onset of disc degeneration exists in rare diseases such as alkaptonuria. It would appear that such a constitutional factor operates also in simple disc degeneration, since persons who have cervical disc degeneration are more likely to have degenerative changes in the lumbar discs. Our data offer no evidence that this factor is occupational.

The present study confirms the greater involvement of the cervical and lumbar spine in males than in females. The sex difference seems to be mainly of severity, minimal changes showing no sex difference. An examination of the prevalence in occupational groups indicates that the sex distribution probably depends more on occupational differences between the sexes than on any hormonal or other influence. In the case of the lumbar spine, for example, the more strenuous occupations, such as coal-mining, outdoor work such as farming and road-making, and unskilled labouring, are associated with the highest prevalence. In the cervical spine, the occupational factors are less obvious, but the coalminers and unskilled labourers appear to have the most severe changes. This association with heavy manual work indicates that strains and minor traumata play an important part in causation. 
The data presented in this paper make it clear that there is an association between disc degeneration and pain, and that persons with severe changes in the disc are more likely to have episodes of pain in the corresponding distribution. Injection of saline into a degenerate lumbar disc can reproduce the symptoms in the back and leg according to Hirsch (1948), and it has been suggested by Petter (1933) and by Charnley (1952) that the symptoms may arise as a result of swelling of the disc from its affinity for water. Our findings, however, indicate that symptoms are more likely to arise when the disc is narrowed and similar conclusions have been reached by Friedenberg and Miller (1963). Thus it would seem more likely that symptoms arise from the surrounding ligamentous structures from lack of stability of the spine due to loss of disc turgor and diminished disc height. This would explain the episodic nature of the pain and its onset after quite trivial strains in most cases. The absence of related symptoms in persons with dorsal disc degeneration (Lawrence and others, 1963) would confirm this view since the discs in this region are relatively thin and the support afforded by the thoracic cage would moreover tend to counter any instability arising from degenerate discs.

\section{Local and Referred Pain}

The pain in disc degeneration might be expected to be either local or referred, depending on whether it arises from superficial or deep ligaments. In a series of 152 patients attending the Walkden Miners' Clinic with pain in the trunk and limbs associated with disc degeneration, the distribution of symptoms and $x$-ray changes was as shown in Fig. 8 . The symptoms are expressed as a segmental distribution in accordance with the data of Kellgren $(1939,1940)$ and Lewis $(1942)$, so that, for example, a pain in the back felt at the level of the L3 posterior spinuous process is designated D12 (Fig. 7). This is done so that trunk and limb pains can be included in a uniform nomenclature. Radiological changes were most frequently encountered at $\mathrm{C} 6$ and $\mathrm{L} 3$ in this series. The symptom distribution curve on the other hand showed three peaks at C5, D12-L2, and L5.

When the relationship between $x$-ray changes and symptoms was studied in detail, it was found that pain felt in the upper gluteal region (L1, L2 and L3) was associated chiefly with L3 disc involvement. Indeed where a single disc only was involved in patients with L2 pain, it was nearly always L3. This was also the most commonly affected disc in patients with D12 and L1 pain (lower and midlumbar pain, i.e. pain in the region of the L3). It would thus appear that the pain in L3 disc involvement may be felt locally or sometimes referred. (In any case precise segmental correspondence would be unlikely, since the posterior surface of the annulus in the lumbar region is supplied by the? descending nerve of Roofe.) Patients with D12
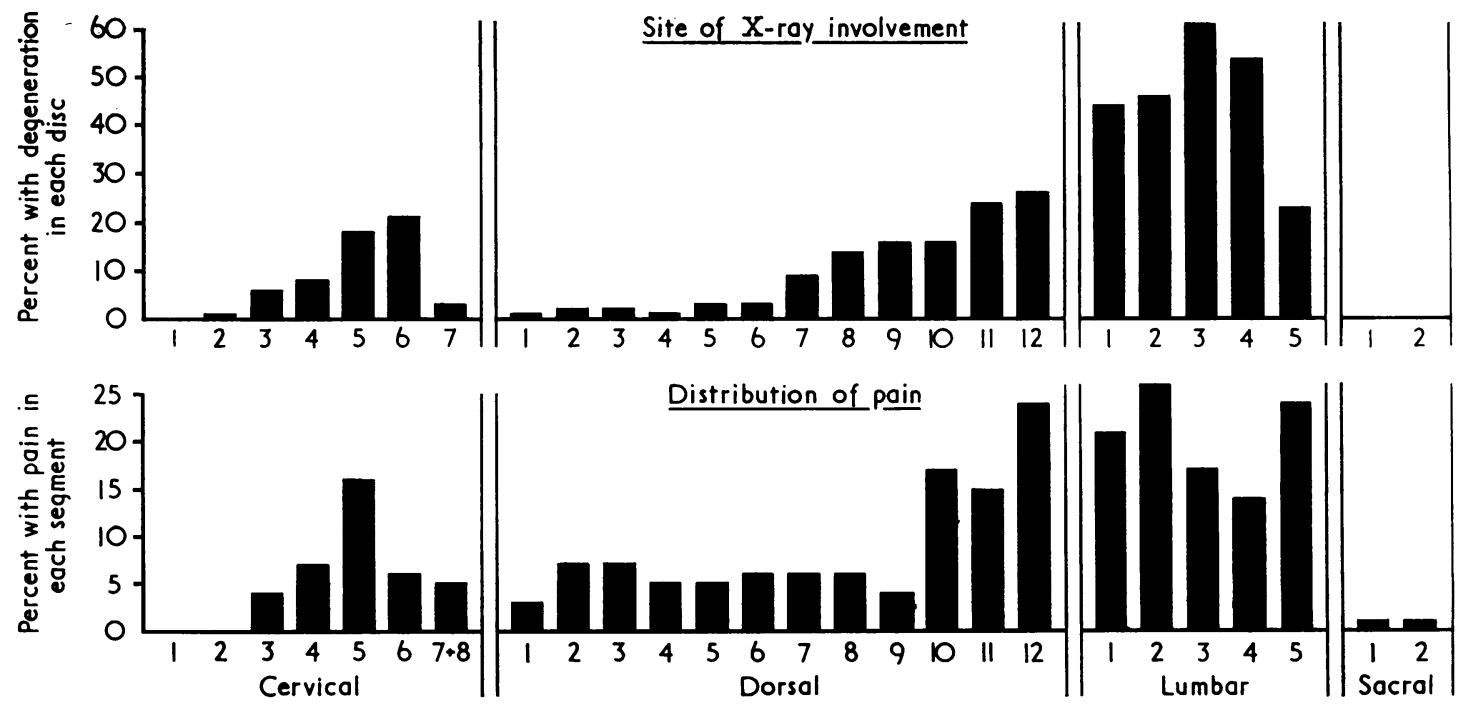

Fig. 8.-Comparison of $x$-ray changes and distribution of pain in patients with segmental back and hip pain and $x$-ray evidence of disc degeneration, shown according to disc involved. 
and $\mathbf{L} 1$ and $\mathrm{L} 2$ disc degeneration had symptoms similarly related, but in D7-11 disc involvement, the pain was usually felt at D10, i.e. at the dorso-lumbar junction.

The L5 segmental pain was associated most commonly with L4 disc involvement, but where only a single disc was involved in patients with L5 pain, it was equally likely to be L4 or L5. C5 (shoulder) pain was most often association with $\mathrm{C5}$ disc degeneration, but almost as often with $\mathrm{C} 6$, and where only a single disc was affected it might equally be $\mathrm{C} 5$ or $\mathrm{C} 6$.

The relative importance of disc degeneration and of other musculo-skeletal disorders as a cause of back and sciatic pain may be briefly considered here. Of the 812 persons with grade 2-4 lumbar disc degeneration in our population samples, 57 per cent. had pain compared with 44 per cent. of those without disc degeneration (Table X). Thus, in 106 persons (13 per cent.), the symptoms could be attributed to the disc degeneration. By the same argument 9 per cent. of the 277 with osteoarthrosis had symptoms because of their disease (i.e. only 25 persons) 37 per cent. of the 33 with rheumatoid arthritis of the lumbar spine had symptoms because of their disease (i.e. 12 persons), and spondylitis would be responsible for this back-hip-sciatic pain in three persons. These figures, though they indicate the relative importance of each disease as a cause of back-hip-sciatic pain, are clearly minimal. For example, the true value for pain due to disc degeneration could lie anywhere between 13 and 57 per cent., and for spondylitis anywhere between 49 and 100 per cent., since some may have had pain due to their radiological disease in addition to other causes of back-hip-sciatic pain. The figures for disc degeneration may have been even higher since many may have forgotten previous episodes of pain. The importance of non-radiological lesions as a cause of pain cannot be assessed in this way, but it seems clear that they are responsible for a large proportion of the attacks of back-hip-sciatic pain which occur in the population. Disc prolapse would appear to have been responsible in eighty, only 51 of whom had radiological evidence of disc degeneration. In the same way it can be shown that, in at least 13 per cent. of those with cervical disc degeneration, the cervico-brachial pain may have been secondary to the degenerative changes.

Our failure to find paraplegia in persons with cervical disc degeneration does not contradict the findings of Spillane and Lloyd (1951), since their twelve cases were drawn from a very much larger population, probably of the order of 700,000 .

\section{Summary}

The prevalence of intervertebral disc degeneration has been investigated in 1,803 males and 1,572 females aged 15 and over examined in population surveys in the United Kingdom. Routine $x$ rays were taken of the cervical and lumbar spine, the cervical spine from age 15 and the lumbar spine from age 35 onwards. In the cervical spine, 42 per cent. of males and 37 per cent. of females had definite evidence of disc degeneration, but this was minimal in 21 and 20 per cent. respectively. Lumbar disc degeneration was present in 65 per cent. of males and 52 per cent. of females aged 35 and over, but was minimal in 45 and 39 per cent. The prevalence increased with age in both sexes. There was a relationship between cervical disc degeneration and neck-shoulder-brachial pain in both sexes, but only in those with moderate or severe disease with narrowed discs was this significant. The degeneration was mainly related to a past episode of pain or to repeated episodes, but in severe cases the pain might last 2 years or more.

There was a relationship between lumbar disc degeneration and back-hip-sciatic pain. It was significant both for minimal and for moderate and severe changes in males, but the association was less striking in females and was significant only for moderate or severe disease. The pain was mainly episodic, starting at age 40 to 50 . It was estimated

TABLE $\mathbf{X}$

CAUSES OF BACK-HIP-SCIATIC PAIN IN LEIGH, WENSLEYDALE AND WATFORD

\begin{tabular}{|c|c|c|c|c|c|c|c|c|c|}
\hline \multirow{4}{*}{$\begin{array}{c}\text { Radiological } \\
\text { Diagnosis }\end{array}$} & \multirow{4}{*}{$\underset{X \text {-rayed }}{\text { Total }}$} & \multicolumn{6}{|c|}{ Grade of Radiological Change } & \multicolumn{2}{|c|}{ Pain due to Disease } \\
\hline & & \multicolumn{3}{|c|}{ Grade $2-4$} & \multicolumn{3}{|c|}{ Grade 0-1 } & \multirow{3}{*}{$\begin{array}{l}\text { Percentage } \\
\text { of } \\
\text { Grade } 2-4\end{array}$} & \multirow{3}{*}{$\begin{array}{c}\text { No. } \\
\text { of } \\
\text { Grade 2-4 }\end{array}$} \\
\hline & & \multirow{2}{*}{$\underset{X \text {-rayed }}{\text { Total }}$} & \multicolumn{2}{|c|}{ With Pain } & \multirow{2}{*}{$\underset{X \text {-rayed }}{\text { Total }}$} & \multicolumn{2}{|c|}{ With Pain } & & \\
\hline & & & No. & Per cent. & & No. & Per cent. & & \\
\hline $\begin{array}{l}\text { Disc Degeneration } \\
\text { Osteo-Arthrosis } \\
\text { Rheumatoid Arthritis } \\
\text { Ankylosing Spondylitis }\end{array}$ & $\begin{array}{l}1,522 \\
1,522 \\
1,522 \\
1,522\end{array}$ & $\begin{array}{r}812 \\
277 \\
33 \\
6\end{array}$ & $\begin{array}{r}462 \\
161 \\
29 \\
6\end{array}$ & $\begin{array}{r}57 \\
58 \\
88 \\
100\end{array}$ & $\begin{array}{r}710 \\
1,245 \\
1,489 \\
1,516\end{array}$ & $\begin{array}{l}320 \\
618 \\
753 \\
776\end{array}$ & $\begin{array}{l}44 \\
49 \\
51 \\
51\end{array}$ & $\begin{array}{r}13 \\
9 \\
37 \\
49\end{array}$ & $\begin{array}{r}106 \\
25 \\
12 \\
3\end{array}$ \\
\hline
\end{tabular}


that, in at least 13 per cent. of those with disc degeneration, the symptoms of pain were due to the disease, and that disc degeneration is a more common cause of back-hip-sciatic pain than disc prolapse, osteo-arthrosis, rheumatoid arthritis, or ankylosing spondylitis.

A history or signs of nerve root involvement was found in only 1.7 per cent. of the 662 persons with moderate or severe cervical disc degeneration and in 10 per cent. of the 224 with moderate or severe lumbar disc degeneration. Obvious symptoms and signs of cervical myelopathy were not encountered, but these were not specifically looked for in the technique of the survey.

In a series of 152 patients with disc degeneration seen at a rehabilitation centre during an episode of pain, symptoms were found to be either local or in the segmental distribution for pain from the corresponding ligaments. It is suggested that symptoms arise as a result of strains or tears of spinal ligaments resulting from stresses produced by the narrow disc and the associated instability.

No relationship was found between damp housing and the complaint rate in persons with disc degeneration.

There were significant occupational differences. Disc degeneration in the lumbar spine was most frequent in miners and outdoor workers, in unskilled labourers, and in workers in heavy industry, and arose at an earlier age in these occupations.

Cervical disc degeneration was also found in its most severe form in miners and unskilled workers. Business and professional men had a high frequency, but in them the disease was minimal.

I should like to express my gratitude to Prof. J. H. Kellgren for much help and advice in the preparation of this paper. I am indebted to Messrs. Blackwell of Oxford and the Department of Medical Illustration, Royal Infirmary, Manchester, for permission to reproduce Figs. 1 and 2.

\section{REFERENCES}

Ansell, B. M., and Lawrence, J. S. (1966). Ann. rheum. Dis., 25, 67 (Fluoridation and the rheumatic diseases).

"Atlas of Standard Radiographs of Arthritis" (1963). "Epidemiology of Chronic Rheumatism", vol. 2. Blackwell, Oxford.

Ball, J., and Lawrence, J. S. (1966). Ann. rheum. Dis., 20, 235 (Epidemiology of the sheep cell agglutination test).

Brain, R. (1954). Lancet, 1, 687 (Spondylosis-The known and the unknown).

Bremner, J. H. (1961). Ann. rheum. Dis., 20, 149 (Rheumatic complaints in a rural population).

Caplan, P. S., Freedman, L. M. J., and Connelly, T. P. (1966). Arthr. and Rheum., 9, 693 (Degenerative joint disease of the lumbar spine in coal miners-A clinical and X-ray study).

Charnley, J. (1952). Lancet, 1, 124 (The imbibition of fluid as a cause of herniation of the nucleus pulposus).

Chrispin, A. R., and Lees, S. F. (1963). J. Neurol. Neurosurg. Psychiat., 26, 166 (The spinal canal in cervical spondylosis).

Collins, D. H. (1949). "The Pathology of Articular and Spinal Diseases". Arnold, London.

Epstein, J. A., Epstein, B. S., and Lavine, L. S. (1963). Arch. Neurol. (Chicago), 8, 307.

Frykholm, R. (1951). Acta chir. scand., 101, 345 (Lower cervical vertebrae and intervertebral discs. Surgical anatomy and pathology).

Friedenberg, Z. B., and Miller, W. T. (1963). J. Bone Jt Surg., 45A, 1171 (Degenerative disc disease of the cervical spine- a comparative study of asymptomatic and symptomatic patients).

Greenfield, J. G. (1953). Rev. méd. Suisse rom., 73, 227 (Malformations et dégénérescences des disques intervertebraux de la région cervicale).

Hirsch, C. (1948). Acta orthop. scand., 18, 132 (An attempt to diagnose the level of a disc lesion clinically by disc puncture).

Kellgren, J. H. (1939). Clin. Sci., 4, 35 (On the distribution of pain arising from deep somatic structures with charts of segmental pain areas). (1940). Ibid., 4, 303 (Somatic simulating visceral pain).

- and Lawrence, J. S. (1952). Brit. J. industr. Med., 9, 197 (Rheumatism in miners-Part II: $\mathrm{X}$-ray study). (1958). Ann. rheum. Dis., 17, 388 (Osteo-arthrosis and disc degeneration in an urban population).

Lawrence, J. S., and Bennett, P. H. (1960). Ibid., 19, 20 (Benign polyarthritis).

-, Bremner, J. M., and Bier, F. (1966). Ibid., 25, 1 (Osteo-arthrosis). 
- de Graaff, R., and Laine, V. A. I. (1963). In "The Epidemiology of Chronic Rheumatism", vol. 1, ed. J. H. Kellgren, M. R. Jeffrey, and J. Ball, p. 98 . Blackwell, Oxford.

Lewis, T. (1942). "Pain". Macmillan, New York.

Pallis, C., Jones, A. M., and Spillane, J. D. (1954). Brain, 77, 274 (Cervical spondylosis: Incidence and implications).

Payne, E. E., and Spillane, J. D. (1957). Ibid., 80, 571 (The cervical spine: An anatomico-pathological study of 70 specimens with particular reference to the problem of cervical spondylosis).

Petter, C. K. (1933). J. Bone Jt Surg., 15, 365 (Methods of measuring the pressure of the intervertebral disc).

Rokitanski, C. (1855). "Lehrbuch der patholoqische Anatomie". Wien.

Schmorl, G. (1929). Klin. Wschr., 8, 1243 (Zur pathologischen Anatomie der Wirbelsäule).

— and Junganns, H. (1951). "Die gesunde und kranke Wirbelsaule in Rontgenbild und Klinik". Stuttgart.

Spillane, J. D., and Lloyd, G. H. T. (1951). Lancet, 2, 653 (Spastic paraplegia in late adult life).

Wenzel, C. (1824). "Ưber die Krankheiten am Rückgrat”. Wesche, Bamberg.

Wilkinson, M. (1960). Brain, 83, 589 (The morbid anatomy of cervical spondylosis and myelopathy).

La dégénérescence du disque intervertébral. Sa fréquence et sa relation avec les symptômes

RÉSUMÉ

La fréquence de la dégénérescence du disque intervertébral a été examinée chez 1,803 hommes et 1,572 femmes agés de 15 ans et au-dessus dans des relevés de population au Royaume-Uni. Des radiographies de routine avaient été prises de la région cervicale et lombaire de la colonne vertébrale, la région cervicale à partir de 15 ans et de la région lombaire à partir de 35 ans et au-dessus. Dans la région cervicale 42 pour cent des hommes et 37 pour cent des femmes avaient des manifestations définies de dégénérescence du disque, mais cela était minimal chez 21 et 20 pour cent des cas respectivement, la dégénérescence des disques lombaires était présente chez 65 pour cent des hommes et 52 pour cent des femmes âgées de 35 ans ou plus, mais était minimale chez 45 et 39 pour cent respectivement. Chez les deux sexes, la fréquence augmentait avec l'âge.

Il y avait une relation entre la dégénérescence du disque cervical et le syndrome douleur-cou-épaulebrachiale chez les deux sexes, mais cela était significatif seulement chez ceux atteints de maladie modérée ou grave avec des disques retrécis. La dégénérescence était surtout en relation à un épisode douloureux antérieur ou à des épisodes répétés, mais dans des cas graves la douleur pouvait durer deux ans ou plus.

Il y avait une relation entre la dégénérescence du disque lombaire et le syndrome douleur-dos-hanche-sciatique. Il était marqué chez les patients avec des changements minimes, modérés ou sérieuses, mais l'association de douleur était moins marquée chez les femmes et était significative seulement dans les cas de maladies modérées ou graves. La douleur était surtout épisodique commençant à l'âge de $\mathbf{4 0}$ à 50 ans. Il a été estimé que, dans au moins 13 pour cent des cas ou il y avait une dégénérescence du disque les symptômes de douleur étaient dues à la maladie et que la dégénérescence du disque est une cause moins rare du syndrome douleur-dos-hanchesciatique que le prolapsus du disque, l'ostéo-arthrose, l'arthrite rhumatoïde ou la spondylarthrite ankylosante.

Un historique d'affection du ganglion avait été trouvé chez 1,7 pour cent des 662 personnes ayant une dégénérescence modérée ou grave du disque cervical et chez 10 pour cent des 224 ayant une dégénérescence modérée ou grave du disque lombaire. Des symptômes évidents D
Degeneración de disco, su frecuencia y relación con sintomas

\section{SUMARIO}

La frecuencia de degeneración de disco intervertebral ha sido investigada en 1.803 hombres y 1.572 mujeres de 15 o más años de edad, a la luz de encuestas de población realizadas en el Reino Unido. Se tomaron radiografías de rutina de las regiones cervical y lumbar del espinazo, la cervical de los 15 años para arriba y la lumbar de los 35 años para adelante. En los casos de espinazo cervical, un $\mathbf{4 2}$ por ciento de los hombres y un 37 por ciento de las mujeres mostraron evidencias concluyentes de degeneración de disco, pero esto era mínimo en un 21 y un 20 por ciento, respectivamente. La degeneración de disco lumbar se hallaba presente en un 65 por ciento de hombres y en un 52 por ciento de mujeres de 35 y más años de edad, pero era mínima en un 45 y un 39 por ciento. La frecuencia aumentó con la edad en ambos sexos.

Había una relación entre la degeneración de disco cervical y el dolor cuello-hombro-braquial en ambos sexos, pero era significativa solamente en los pacientes con enfermedad moderada o severa con discos encogidos. La degeneración se relacionó principalmente con un período pasado de dolor o con períodos repetidos, pero en casos severos el dolor podría durar dos años o más. Había una relación entre la degeneración de disco lumbar y el dolor dorsal y ciático. Eran significativos tanto por cambios mínimos como por moderados y severos en las mujeres, pero la asociación era menos notoria en las mujeres y significativa solamente en enfermedades moderadas o severas. El dolor era principalmente episódico, comenzando a la edad de entre 40 y 50 años. Se calculó que, por lo menos en un 13 por ciento de pacientes con degeneración de disco, los síntomas del dolor se debían a la enfermedad, y que la degeneración de disco es una causa más común del dolor dorsal y ciático que el prolapso de disco, la osteoartrosis, la poliartritis reumatoide o la espondilitis anquilosante.

Se descubrió una historia (o indicios) de afección a la raíz nerviosa en solo un 1,7 por ciento de las 662 personas con degeneración de disco cervical moderada o severa y en un 10 por ciento de las 224 con degeneración de disco lumbar moderada o severa. No se hallaron síntomas ni señales evidentes de mielopatía cervical, 
et des signes de myelopathie cervicale n'avaient pas été rencontrés, mais n'avaient pas été recherchés spécifiquement durant la technique du relevé.

Dans une série de 152 malades ayant une dégénérescence du disque vus à un centre de réhabilitation pendant un épisode de douleur, les symptômes ont été trouvés localement ou dans la distribution segmentale de la douleur provenant des ligaments correspondants. Il est suggéré que les symptômes proviennent du résultat des tensions ou des déchirures des ligaments spinaux causées par le stress produit par le disque rétréci ou l'instabilité associée.

Aucune relation n'a été trouvée entre les maisons humides et le taux de morbidité chez les personnes atteintes d'une dégénérescence du disque.

Il y avait des différences marquées entre les occupations. La dégénérescence du disque dans la région lombaire était plus fréquente chez les mineurs et les travailleurs au grand air, chez les manoeuvres, et chez les ouvriers des industries lourdes, et commençait plus tôt chez ces travailleurs.

La dégénérescence du disque cervical a été aussi vue dans sa forme la plus grave chez les mineurs et les travailleurs inexpérimentés. Les professionnels et les hommes d'affaires montraient un taux élevé mais chez eux la maladie était minimale. pero estas no fueron buscadas específicamente en la técnica de la encuesta.

En una serie de 152 pacientes con degeneración de disco, examinados en centros de rehabilitación durante un período de dolor, se descubrió que los síntomas eran o bien locales o bien en la distribución segmental del dolor de los ligamentos correspondientes. Se sugiere que los síntomas se presentan como resultado de esfuerzos o desgarraduras de los ligamentos espinales, derivados de esfuerzos producidos por el disco encogido y la inestabilidad asociada.

No se halló relación alguna entre las viviendas húmedas y la proporción de casos de personas con degeneración de disco. Había diferencias ocupacionales significativas. La degeneración de disco en la región lumbar era más frecuente en mineros y obreros que trabajaban al aire libre, en trabajadores no calificados y en obreros de la industria pesada, y se presentó a edad más temprana en estas ocupaciones.

También se descubrió degeneración de disco cervical, en su forma más severa, en mineros y obreros no calificados. Los hombres de negocios y los profesionales presentaban una frecuencia elevada, pero en ellos la is enfermedad era mínima. 